\title{
Feeding by common heterotrophic protist predators on seven Prorocentrum species
}

\author{
Ji Hyun You ${ }^{1}$, Hae Jin Jeong ${ }^{1,2, *}$, Hee Chang Kang ${ }^{1}$, Jin Hee Ok ${ }^{1}$, Sang Ah Park ${ }^{1}$ and \\ An Suk Lim ${ }^{3}$
}

${ }^{1}$ School of Earth and Environmental Sciences, College of Natural Sciences, Seoul National University, Seoul 08826, Korea ${ }^{2}$ Research Institute of Oceanography, Seoul National University, Seoul 08826, Korea

${ }^{3}$ Division of Life Science, Gyeongsang National University, Jinju 52828, Korea

\begin{abstract}
Species belonging to the dinoflagellate genus Prorocentrum are known to cause red tides or harmful algal blooms. To understand the dynamics of a Prorocentrum sp., its growth and mortality due to predation need to be assessed. However, there are only a few Prorocentrum spp. for which heterotrophic protist predators have been reported. We explored feeding by the common heterotrophic dinoflagellates Gyrodinium dominans, Oxyrrhis marina, Pfiesteria piscicida, Oblea rotunda, and Polykrikos kofoidii and the naked ciliate Strombidinopsis sp. (approx. $90 \mu \mathrm{m}$ cell length) on the planktonic species Prorocentrum triestinum, $P$. cordatum, $P$. donghaiense, $P$. rhathymum, and $P$. micans as well as the benthic species $P$. lima and $P$. hoffmannianum. All heterotrophic protists tested were able to feed on the planktonic prey species. However, O. marina and O. rotunda did not feed on P. lima and P. hoffmannianum, while G. dominans, P. kofoidii, and Strombidinopsis sp. did. The growth and ingestion rates of $G$. dominans and P. kofoidii on one of the seven Prorocentrum spp. were significantly different from those on other prey species. G. dominans showed the top three highest growth rates when it fed on P. triestinum, $P$. cordatum, and $P$. donghaiense, however, $P$. kofoidii had negative growth rates when fed on these three prey species. In contrast, $P$. kofoidii had a positive growth rate only when fed on $P$. hoffmannianum. This differential feeding on Prorocentrum spp. between G. dominans and P. kofoidii may provide different ecological niches and reduce competition between these two common heterotrophic protist predators.
\end{abstract}

Key Words: ciliate; dinoflagellate; harmful algal bloom; protist; red tide

Abbreviations: ESD, equivalent spherical diameter; HAB, harmful algal bloom; HSD, honestly significant difference; HTD, heterotrophic dinoflagellate; $I_{\max }$, maximum ingestion rate; $K_{\mathrm{GR}}$, prey concentration sustaining $1 / 2 \mu_{\max } ; K_{\mathrm{IR}}$, prey concentration sustaining $1 / 2 I_{\max } ; \mu_{\max }$, maximum growth rate; OA, okadaic acid; SRC, Sedgewick Rafter chamber

\section{INTRODUCTION}

Dinoflagellates are ubiquitous in marine environments (Kudela and Gobler 2012, Jeong et al. 2013, Lee et al. 2018, 2019b, Leles et al. 2019). They play diverse roles in marine food webs as primary producers, prey, and predators (Mallin et al. 1991, Hansen 1992, Psarra et al. 2000, Jeong et al. 2010, Anderson and MendenDeuer 2017, Kang et al. 2019). They often form red tides or harmful algal blooms (HABs), causing human illness and the large-scale mortality of finfish and shellfish (Hallegraeff 1992, Khan et al. 1997, Azanza et al. 2005, Backer
(9) This is an Open Access article distributed under the terms of the Creative Commons Attribution Non-Commercial License (http://creativecommons.org/licenses/by-nc/3.0/) which permits unrestricted non-commercial use, distribution, and reproduction in any medium, provided the original work is properly cited.
Received January 27, 2020, Accepted February 28, 2020

* Corresponding Author

E-mail: hjjeong@snu.ac.kr

Tel: +82-2-880-6746, Fax: +82-2-874-9695 
and McGillicuddy 2006, Jeong et al. 2017). To minimize losses due to red tides or HABs, the population dynamics of red-tide dinoflagellate species should be elucidated (Wyatt and Zingone 2014, Jeong et al. 2015). The growth and mortality of red-tide dinoflagellates due to predation are two critical parameters in their population dynamics (Franklin et al. 2006, Jeong et al. 2015). While there have been many studies reporting the growth rates of red-tide dinoflagellates, there have been fewer studies on their mortality due to predation (Smayda 1997, Matsubara et al. 2007, Jeong et al. 2010, Lee et al. 2019a); the mortality of red-tide dinoflagellates due to predation should be explored.

Species in the dinoflagellate genus Prorocentrum are known to cause red tides or HABs (Labib 1996, Heil et al. 2005, Pearce et al. 2005, Chen et al. 2006, Ingarao et al. 2009, Kang et al. 2013). To understand the dynamics of a Prorocentrum sp., its growth and mortality due to predation need to be assessed. However, there are only a few Prorocentrum spp. for which heterotrophic protist predators have been reported (Jeong et al. 2010); many mixotrophic and heterotrophic protist predators of Prorocentrum cordatum (Ostenfeld) J. D. Dodge $(=P$. minimum) and P. micans Ehrenberg have been found (Strom and Buskey 1993, Nakamura et al. 1995, Lee 1998, Jeong et al. 1999b, 2001b, Kim and Jeong 2004); P. donghaiense D. Lu is known to be eaten by Oxyrrhis marina Dujardin (An et al. 2016) and P. lima (Ehrenberg) F. Stein is fed on by Polykrikos kofoidii Chatton (Matsuoka et al. 2000). Some Prorocentrum spp. are planktonic, whereas others are benthic (Faust 1990, Nagahama et al. 2011, Hoppenrath et al. 2013). Furthermore, some species are toxic, and others are not (Murakami et al. 1982, Yasumoto et al. 1987, Morton et al. 1994, Dam and Colin 2005, SierraBeltrán et al. 2005, Zingone et al. 2006, Sugahara et al. 2011). Prorocentrum spp. vary widely in size (10-50 $\mu \mathrm{m})$ (Hoppenrath et al. 2013, Lim et al. 2013, Jeong et al. 2015). Thus, a heterotrophic protist predator may respond differently to different Prorocentrum spp. Meanwhile, there are several heterotrophic dinoflagellate and ciliate predators that are commonly found in diverse marine environments (Lewis 1990, Strom and Buskey 1993, Nakamura et al. 1995, Jeong et al. 1999b, 2006, Coyne et al. 2001, Lowe et al. 2005, Claessens et al. 2008, Watts et al. 2010, Calbet et al. 2013, Tillmann and Hoppenrath 2013). Thus, to understand the population dynamics of a Prorocentrum sp., feeding by these common heterotrophic protists on Prorocentrum spp. should be explored.

In this study, we explored feeding by the common heterotrophic dinoflagellates (HTDs) Gyrodinium dominans
Hulbert, Oblea rotunda (Lebour) Balech ex Sournia, $O$. marina, Pfiesteria piscicida Steidinger \& J. M. Burkholder, and Polykrikos kofoidii and the naked ciliate Strombidinopsis sp. (approximately $90 \mu \mathrm{m}$ in cell length) on P. cordatum, $P$. donghaiense, $P$. hoffmannianum M. A. Faust, $P$. lima, P. micans, P. rhathymum A. R. Loeblich III, Sherley \& R. J. Schmidt, and P. triestinum J. Schiller. Prorocentrum cordatum, $P$. triestinum, $P$. donghaiense, and $P$. rhathymum are planktonic species, while $P$. lima and $P$. hoffmannianum are benthic species (Hoppenrath et al. 2013, Jeong et al. 2017). P. cordatum, P. donghaiense, and P. triestinum are considerably smaller in size than are $P$. rhathymum and P. micans. Additionally, P. hoffmannianum and P. lima are larger than the other five Prorocentrum spp. Thus, several factors affecting feeding by heterotrophic protists on Prorocentrum spp. can be examined. HTDs feed on prey cells in various ways: O. marina and Gyrodinium dominans feed by direct engulfment, Polykrikos kofoidii feeds by engulfment after anchoring a prey cell using a taeniocyst-nematocyst complex, Oblea rotunda feeds using a pallium after anchoring prey cells using a tow filament, and Pfiesteria piscicida feeds using a peduncle. In addition, the naked ciliate Strombidinopsis sp. feeds by direct engulfment after generating a feeding current (Barker 1935, Westfall et al. 1983, Gaines and Taylor 1984, Hansen 1991, Burkholder and Glasgow 1997, Verni and Gualtieri 1997). Thus, whether the feeding mechanisms of the heterotrophic protist predators affect feeding or not can be explored.

Using clonal cultures of these Prorocentrum spp. and the heterotrophic protists, we investigated whether each predator feeds on each Prorocentrum sp. Furthermore, we measured the growth and ingestion rates of G. dominans on P. donghaiense and P. kofoidii on P. hoffmannianum as functions of prey concentration. We also measured the growth and ingestion rates of G. dominans and $P$. kofoidii on the other Prorocentrum spp. at single high prey concentrations. The results of this study may provide a basis for understanding the feeding by heterotrophic protist predators on Prorocentrum spp. in marine food webs and the dynamics of these predators and prey species.

\section{MATERIALS AND METHODS}

\section{Preparation of experimental organisms}

Cells of Prorocentrum triestinum, P. cordatum, P. donghaiense, P. lima, P. rhathymum, and P. micans were isolat- 
ed from Korean coastal waters, and clonal cultures were established using two serial single-cell isolations (Table 1). A culture of $P$. hoffmannianum (CCMP683) isolated from the Caribbean Sea was obtained from the National Center for Marine Algae and Microbiota (NCMA), USA (Table 1). All cultures were maintained in $250-\mathrm{mL}$ flasks containing f/2-Si or L1-Si medium (Guillard and Ryther 1962, Guillard and Hargraves 1993), placed on a shelf at $20^{\circ} \mathrm{C}$ under $20 \mu \mathrm{mol}$ photons $\mathrm{m}^{-2} \mathrm{~s}^{-1}$ illumination provided by cool-white fluorescent light with a $14: 10 \mathrm{~h}$ light / dark cycle. The carbon content of each Prorocentrum sp. was estimated from the cell volume according to Strathmann (1967).

To establish cells of G. dominans, Oxyrrhis marina, Oblea rotunda, and Polykrikos kofoidii, plankton samples were collected from water samples of Korean coastal waters during 2001-2019 (Table 2). A clonal culture of each species was established by two serial single-cell isolations. The culture of Pfiesteria piscicida was obtained from the NCMA. Moreover, to obtain cells of the ciliate Strombidinopsis sp. (approximately $90 \mu \mathrm{m}$ in cell length), plankton samples were collected using a $10 \mu \mathrm{m}$ mesh net from the waters of Masan Bay, Korea, in January 2018, when the water temperature and salinity were $5.6^{\circ} \mathrm{C}$ and 33.0, respectively (Table 2). A clonal culture of Strombidinopsis sp. was established by two serial single-cell isola- tions. The cell volumes of the predators were estimated using the methods of Kim and Jeong (2004) for G. dominans, Ok et al. (2017) for O. rotunda, Jeong et al. (2001a) for O. marina, Jeong et al. (2001b) for P. kofoidii, Jeong et al. (2007) for P. piscicida, and Kang et al. (2018) for Strombidinopsis sp. (Table 2).

\section{Feeding by heterotrophic protists on each Pro- rocentrum species}

Experiment (Expt.) 1 was designed to investigate the predator-prey relationship between each of the seven Prorocentrum spp. and each of the six heterotrophic protists after one prey species was provided to one predator species.

A dense culture of each Prorocentrum sp. was added to a 42-mL polycarbonate (PC) bottle containing each of the HTDs and added to a well of a 6-well plate chamber containing the ciliate (Table 3). One predator control bottle or well (without Prorocentrum prey species) and one prey control bottle or well (without heterotrophic protist predators) were set up for each experiment. The bottles were placed on a plankton wheel rotating at 0.9 $\mathrm{rpm}(0.00017 \mathrm{~g})$ and incubated at $20^{\circ} \mathrm{C}$, under $20 \mu \mathrm{mol}$ photons $\mathrm{m}^{-2} \mathrm{~s}^{-1}$ illumination provided by cool-white fluorescent light with a $14: 10 \mathrm{~h}$ light / dark cycle. The 6-well

Table 1. Information on the isolation and maintenance of seven Prorocentrum spp.

\begin{tabular}{lllllccc}
\hline \multicolumn{1}{c}{ Organisms } & Strain name & ESD & CV & \multicolumn{1}{c}{ Location } & Time & T & S \\
\hline Prorocentrum triestinum & PTMS0205 & 11.8 & 0.9 & Masan, Korea & May 2002 & - & - \\
P. cordatum (= P. minimum) & PMKS9906 & 12.1 & 1.1 & Gunsan, Korea & Jun 1999 & 21.1 & 30.1 \\
P. donghaiense & PDYS1407-1 & 13.3 & 1.2 & Yeosu, Korea & Jul 2014 & - & - \\
P. rhathymum & PRJJ0907 & 25.3 & 9.4 & Jeju, Korea & Jun 2012 & 11.4 & 13.3 \\
P. micans & PMSH0910 & 26.0 & 9.2 & Shiwha, Korea & Oct 2009 & 16.8 & 27.0 \\
P. lima & DF-114 & 37.1 & 17.8 & Yeosu, Korea & Nov 2012 & 16.5 & 32.4 \\
P. hoffmannianum & CCMP683 & 43.4 & 25.5 & Caribbean sea, USA & Jan 1985 & - & - \\
\hline
\end{tabular}

ESD, equivalent spherical diameter $(\mu \mathrm{m}) ; \mathrm{CV}$, cell volume $\left(\times 10^{3} \mu \mathrm{m}^{3}\right) ; \mathrm{T}$, temperature $\left({ }^{\circ} \mathrm{C}\right) ; \mathrm{S}$, salinity.

Table 2. Information on the isolation and maintenance of the six potential predator species

\begin{tabular}{|c|c|c|c|c|c|c|c|c|c|c|}
\hline Organisms & Type & FM & ESD & CV & Location & Time & $\mathbf{T}$ & $S$ & PS & PC \\
\hline Pfiesteria piscicida (CCMP 2091) & HTD & $\mathrm{PD}$ & 13.5 & 1.3 & Neuse River, USA & Jan 1998 & - & - & Ac & $\sim 5.0$ \\
\hline Oxyrrhis marina & HTD & EG & 15.6 & 2.0 & Gunsan, Korea & May 2001 & 16.0 & 27.7 & Ac & $10.0-20.0$ \\
\hline Gyrodinium dominans & HTD & EG & 20.0 & 2.0 & Jeongok, Korea & Jul 2019 & 25.2 & 31.9 & Ac & $10.0-20.0$ \\
\hline Oblea rotunda & HTD & $\mathrm{PA}$ & 21.6 & 5.3 & Jinhae bay, Korea & Apr 2015 & 12.6 & 31.2 & Ac & $\sim 10.0$ \\
\hline Polykrikos kofoidii & HTD & EG & 43.5 & 43.0 & Jangheung bay, Korea & Jul 2016 & 23.6 & 26.4 & Am & $\sim 5.0$ \\
\hline Strombidinopsis sp. & NC & FF & 68.5 & 168.1 & Masan bay, Korea & Jan 2018 & 5.6 & 33.0 & Lp & $\sim 5.0$ \\
\hline
\end{tabular}

HTD, heterotrophic dinoflagellate; NC, naked ciliate; FM, feeding mechanism; PD, peduncle feeder; EG, engulfment feeder; PA, pallium feeder; FF, filter feeder; ESD, equivalent spherical diameter $(\mu \mathrm{m})$; CV, cell volume $\left(\times 10^{3} \mu \mathrm{m}^{3}\right) ; \mathrm{T}$, temperature $\left({ }^{\circ} \mathrm{C}\right)$; $\mathrm{S}$, salinity; $\mathrm{PS}$, prey species; Ac, Amphidinium carterae; Am, Alexandrium minutum CCMP1888 (= A. lusitanicum); Lp, Lingulodinium polyedra; PC, prey concentration $\left(\times 10^{3}\right.$ cells $\left.\mathrm{mL}^{-1}\right)$. 
plate chamber was placed on the shelf under the same conditions.

Three milliliter aliquots were removed from each bottle after 2, 24, and $48 \mathrm{~h}$ incubations and transferred into 6-well plate chambers. Approximately 100 cells of each HTD predator and 10 cells of the ciliate in the plate chambers were observed under a dissecting microscope (or inverted microscope), at a magnification of $10-63 \times$ (or 100-400x) to determine whether the predator could feed on the Prorocentrum sp. Cells of the predator containing ingested Prorocentrum cells were photographed on a confocal dish (SPL100350; SPL Life Sciences Co., Ltd., Pocheon, Korea) using a digital camera (Zeiss AxioCam HRc 5; Carl Zeiss Ltd., Göttingen, Germany) attached to a microscope at 200-400× magnification.

\section{Growth and ingestion rates of Gyrodinium domi- nans on Prorocentrum donghaiense as a function of prey concentration}

Expt. 2 was designed to measure the growth and ingestion rates of G. dominans feeding on P. donghaiense as a function of the prey concentration (Table 3). In a preliminary test, among the Prorocentrum spp., $P$. donghaiense supported the highest growth rate of $G$. dominans.

In this experiment, a dense culture of G. dominans growing on the dinoflagellate Amphidinium carterae
Hulburt was transferred into a 250-mL culture flask (Falcon; Corning Inc., New York, NY, USA). The flask was filled to capacity with freshly filtered seawater, capped, and placed on a rotating plankton wheel, and incubated under the conditions described above. To monitor the conditions and interactions between predator and prey species, the flask was periodically removed from the rotating wheel, examined through the surface of the capped bottle using a dissecting microscope, and then returned to the rotating wheel. Once the prey cells were no longer detectable, the flask was maintained without added prey for $2 \mathrm{~d}$. This was carried out to minimize possible residual growth resulting from the ingestion of prey during batch culture. Three 1-mL aliquots from the flask were counted, using a compound microscope, to determine the cell concentration of the predator, and the culture was then used to conduct the experiment.

For Expt. 2, the initial concentrations of G. dominans and $P$. donghaiense were established using an autopipette to deliver predetermined volumes of known cell concentrations to the bottles. Triplicate $42-\mathrm{mL}$ PC experiment bottles (mixtures of predator and prey) and triplicate control bottles (prey only) were set up for each predator-prey combination. Triplicate control bottles containing only predators were also established at one predator concentration. To obtain similar water conditions, the water of the predator culture was filtered through a 0.2-

Table 3. Design of experiments

\begin{tabular}{|c|c|c|c|c|}
\hline \multirow{2}{*}{$\begin{array}{c}\text { Expt. } \\
\text { No. }\end{array}$} & \multicolumn{2}{|c|}{ Prey } & \multicolumn{2}{|c|}{ Predators } \\
\hline & Species & Density (cells $\mathrm{mL}^{-1}$ ) & Species & Density (cells $\mathrm{mL}^{-1}$ ) \\
\hline 1 & $\begin{array}{l}\text { Each of Prorocentrum } \\
\text { triestinum, } \text { P. donghaiense, } \\
\text { P. micans, P. rhathymum, } \\
\text { P. lima, and P. hoffmannianum }\end{array}$ & See Table 4 & $\begin{array}{l}\text { Each of Oxyrrhis marina, } \\
\text { Gyrodinium dominans, } \\
\text { Polykrikos kofoidii, Pfiesteria } \\
\text { piscicida, Oblea rotunda, and } \\
\text { Strombidinopsis sp. }\end{array}$ & See Table 4 \\
\hline 2 & P. donghaiense & $\begin{array}{l}88,170,498,969,4,642 \\
7,816,14,105,19,203 \\
32,707\end{array}$ & G. dominans & $\begin{array}{l}10,7,7,17,41,49,44,51,88 \\
(243)\end{array}$ \\
\hline 3 & P. triestinum & 15,475 & G. dominans & 73 \\
\hline 4 & P. cordatum & 12,779 & G. dominans & 118 \\
\hline 5 & P. rhathymum & 3,019 & G. dominans & 58 \\
\hline 6 & P. micans & 2,020 & G. dominans & 117 \\
\hline 7 & P. lima & 1,683 & G. dominans & 95 \\
\hline 8 & P. hoffmannianum & 1,318 & G. dominans & 192 \\
\hline 9 & P. hoffmannianum & $\begin{array}{l}8,31,86,164,324,739, \\
1,276,1,814\end{array}$ & P. kofoidii & $\begin{array}{l}7,20,17,36,55,76,76,96 \\
(83)\end{array}$ \\
\hline 10 & P. triestinum & 10,977 & P. kofoidii & 52 \\
\hline 11 & P. donghaiense & 8,616 & P. kofoidii & 45 \\
\hline 12 & P. rhathymum & 1,903 & P. kofoidii & 35 \\
\hline 13 & P. lima & 1,019 & P. kofoidii & 84 \\
\hline
\end{tabular}

The numbers in the prey and predator columns are the actual initial densities (cells $\mathrm{mL}^{-1}$ ) of prey and predators. The values within parentheses in the predator column are the predator densities in the control bottles. 
$\mu \mathrm{m}$ disposable syringe filter (DISMIC-25CS type, $25 \mathrm{~mm}$; Advantec, Toyo Roshi Kaisha Ltd., Chiba, Japan) and then added to the prey control bottles in the same amount as that added to the experiment bottles for each predatorprey combination. Similarly, the water of the prey culture was filtered through a $0.2-\mu \mathrm{m}$ disposable syringe filter and then added to the predator control bottles in the same amount as that of the prey culture added into the experimental bottles. All bottles were filled to capacity with freshly filtered seawater and capped. To determine the actual predator and prey densities at the beginning of the experiment, a 5-mL aliquot was removed from each bottle, fixed with $5 \%$ acidic Lugol's solution, and examined with a light microscope to determine predator and prey abundances by enumerating the cells in three 1-mL Sedgewick Rafter chambers (SRCs). The bottles were refilled to capacity with $\mathrm{f} / 2$-Si medium, capped, and placed on a rotating wheel under the conditions described above. The dilution of the cultures associated with refilling the bottles was considered when the growth and ingestion rates were calculated. A 10-mL aliquot was taken from each bottle at $48 \mathrm{~h}$ and fixed with 5\% acidic Lugol's solution. The abundances of predators and prey were determined by counting all or $>300$ cells in three 1 -mL SRCs at $48 \mathrm{~h}$. The conditions of the predators and prey were assessed using a dissecting microscope, as described above, prior to subsampling.

The specific growth rates of G. dominans $\left[\mu\left(\mathrm{d}^{-1}\right)\right]$ were calculated using the following formula:

$$
\mu\left(\mathrm{d}^{-1}\right)=\left[\operatorname{Ln}\left(G_{\mathrm{t}} / G_{0}\right)\right] / t
$$

, where $G_{0}$ and $G_{\mathrm{t}}$ are the concentrations of the predator at 0 and $2 \mathrm{~d}$, respectively.

Data for the growth rates of G. dominans were fitted to a modified Michaelis-Menten equation:

$$
\mu\left(\mathrm{d}^{-1}\right)=\mu_{\max }\left(x-x^{\prime}\right) /\left[K_{\mathrm{GR}}+\left(x-x^{\prime}\right)\right]
$$

, where $\mu_{\max }$ is the maximum growth rate $\left(\mathrm{d}^{-1}\right), x$ is the prey concentration (cells $\mathrm{mL}^{-1}$ or $\mathrm{ng} \mathrm{C} \mathrm{mL}-1$ ), $x^{\prime}$ is threshold prey concentration (the prey concentration where $\mu=0$ ), and $K_{\mathrm{GR}}$ is the prey concentration sustaining $1 / 2$ $\mu_{\max }$. Data were iteratively fitted to the model using DeltaGraph (Red Rock Software Inc., Salt Lake, UT, USA).

The ingestion and clearance rates and mean prey concentrations were calculated using the equations of Frost (1972) and Heinbokel (1978). The incubation time for calculating the ingestion and clearance rates was the same as that for estimating the growth rate. The data for ingestion rates (IRs, cells predator ${ }^{-1} \mathrm{~d}^{-1}$ or ng $\mathrm{C}$ predator ${ }^{-1}$ $\left.\mathrm{d}^{-1}\right)$ of $G$. dominans were fitted into a modified MichaelisMenten equation:

$$
\mathrm{IR}=I_{\max }(x) /\left[K_{\mathrm{IR}}+(x)\right]
$$

, where $I_{\max }$ is the maximum ingestion rate (cells predator $^{-1} \mathrm{~d}^{-1}$ or ng $\mathrm{C}$ predator $\left.{ }^{-1} \mathrm{~d}^{-1}\right), x$ is the prey concentration (cells $\mathrm{mL}^{-1}$ or ng $\mathrm{C} \mathrm{mL}^{-1}$ ), and $K_{\mathrm{IR}}$ is the prey concentration sustaining $1 / 2 I_{\max }$.

\section{Growth and ingestion rates of Gyrodinium domi- nans on all Prorocentrum spp. at single prey concentrations}

Expts. 3-8 were designed to measure the growth and ingestion rates of $G$. dominans on each of P. triestinum, P. cordatum, P. rhathymum, P. micans, P. lima, and P. hoffmannianum at single high prey concentrations (Table 3 ).

In these experiments, 9-10 different prey concentrations for each Prorocentrum sp. were originally set up, but the abundances of G. dominans and the target prey at two or three of the highest prey concentrations were quantified. The growth and ingestion rates of G. dominans on each Prorocentrum sp. and mean prey concentrations were determined as those in Expt. 2. To compare the growth and ingestion rates of G. dominans on each Prorocentrum sp., the growth and ingestion rates of $G$. dominans on each Prorocentrum sp. at a high mean prey concentration, which was similar to that on the other Prorocentrum spp., were selected. Moreover, the growth and ingestion rates of $G$. dominans on P. donghaiense at a similar mean prey concentration to those in Expt. 2 were also selected for this comparison.

\section{Growth and ingestion rates of Polykrikos kofoidii on Prorocentrum hoffmannianum as a function of prey concentration}

Expt. 9 was designed to measure the growth and ingestion rates of $P$. kofoidii on $P$. hoffmannianum as a function of the prey concentration (Table 3). In a preliminary test, among the Prorocentrum spp., only P. hoffmannianum supported a positive growth rate of $P$. kofoidii.

In this experiment, dense cultures of $P$. kofoidii growing on the dinoflagellate Alexandrium minutum Halim CCMP1888 (= A. lusitanicum) were transferred into two 250-mL culture flasks. The flasks were filled to capacity with freshly filtered seawater, capped, placed on a rotating plankton wheel, and incubated under the conditions 
described above. To monitor the conditions and interactions between the predator and prey species, the bottles were periodically removed from the rotating wheel, examined, and then returned. Once the prey cells were no longer detectable, the flasks were maintained without added prey for $1 \mathrm{~d}$. Three 1 -mL aliquots from each flask were counted to determine the cell concentration of the predator.

The process of establishing triplicate experiments and prey and predator control bottles, subsampling, determining the abundances of the predator and prey, and calculating the growth and ingestion rates in this experiment was the same as those in Expt. 2.

\section{Growth and ingestion rates of Polykrikos kofoidii on all Prorocentrum spp. at single prey concen- trations}

Expts. 10-13 were designed to measure the growth and ingestion rates of $P$. kofoidii on each of $P$. triestinum, $P$. donghaiense, P. rhathymum, and P. lima at single high prey concentrations (Table 3). Data on the growth and ingestion rates of $P$. kofoidii on P. cordatum and P. micans at single high prey concentrations were obtained from Jeong et al. (2001b) for comparison.

In these experiments, 9-10 different prey concentrations for each of $P$. lima and P. rhathymum and two different high prey concentrations for each of $P$. donghaiense and $P$. triestinum were originally set up, but the abundances of $P$. kofoidii and the target prey at two of the highest prey concentrations were quantified. The growth and ingestion rates of $P$. kofoidii on each Prorocentrum sp. and mean prey concentrations were determined using the same method as those in Expt. 9. To compare the growth and ingestion rates of $P$. kofoidii on all Prorocentrum spp., the growth and ingestion rates of $P$. kofoidii on each Prorocentrum sp. at a high mean prey concentration, which was similar to those on the other Prorocentrum spp., were selected. Moreover, the growth and ingestion rates of $P$. kofoidii on $P$. hoffmannianum at a similar mean prey concentration to those in Expt. 9 were also selected for this comparison.

\section{Swimming speed}

The (previously unrecorded) swimming speeds of $P$. rhathymum, P. lima, and P. hoffmannianum were measured. The swimming speeds of the four other Prorocentrum spp., G. dominans, and P. kofoidii were obtained from previous studies (Jeong et al. 1999a, 2001b, 2002,
2015, Kim and Jeong 2004, Berdalet et al. 2007).

A dense culture of a target Prorocentrum sp. growing autotrophically in $\mathrm{f} / 2$-Si or L1-Si medium was transferred to a $250-\mathrm{mL}$ culture flask. An aliquot from the flask was added to a 38-mL cell culture flask (BD Biosciences, Bedford, MA, USA) and allowed to acclimatize for $30 \mathrm{~min}$. A video camera was focused on one field (appearing as a circle in the cell culture flask) under a dissecting microscope (SZX10; Olympus, Tokyo, Japan) at $20^{\circ} \mathrm{C}$, and the swimming movement of the cells of the target Prorocentrum sp. was then recorded at $20 \times$ magnification using a video analysis system (SRD-1673DN; Samsung Techwin, Seongnam, Korea). The mean and maximum swimming velocities observed after the first $10 \mathrm{~min}$ were analyzed for all swimming cells moving randomly. The average swimming speed was calculated based on the linear displacement of cells in $1 \mathrm{~s}$ during single-frame playback. The swimming speeds of 20 cells were measured.

\section{Statistical analysis}

Univariate analyses and post-hoc tests were performed to investigate the effects of the seven different Prorocentrum spp. as prey on the growth and ingestion rates of two heterotrophic protists (G. dominans and Polykrikos kofoidii) at single high mean prey concentrations. Prior to the analyses, normality and homogeneity of variance were tested. A one-way ANOVA with Tukey's honestly significant difference (HSD) post-hoc test was performed when both assumptions of normality and homogeneity of variance were satisfied. However, Welch's ANOVA with Games-Howell post-hoc test was conducted when the homogeneity of variance was not satisfied. Moreover, a non-parametric Kruskal-Wallis test and Mann-Whitney $U$ test with Bonferroni correction was conducted when the normality assumption was not satisfied. To assess the differential effects of Prorocentrum spp. on the specific growth and ingestion rates of those two heterotrophic protists, a multivariate analysis of variance (MANOVA) was conducted. Pillai's trace for MANOVA was select$\mathrm{ed}$, as this test is robust to the violation of assumptions (Scheiner 1993). The simple linear regression was used to examine relationships between variables (i.e., equivalent spherical diameters [ESD] of Prorocentrum species, and the growth and ingestion rates of a predator feeding on each Prorocentrum species). All analyses were performed using SPSS ver. 25.0 (IBM-SPSS Inc., Armonk, NY, USA). A 0.05 significance criterion was chosen. 

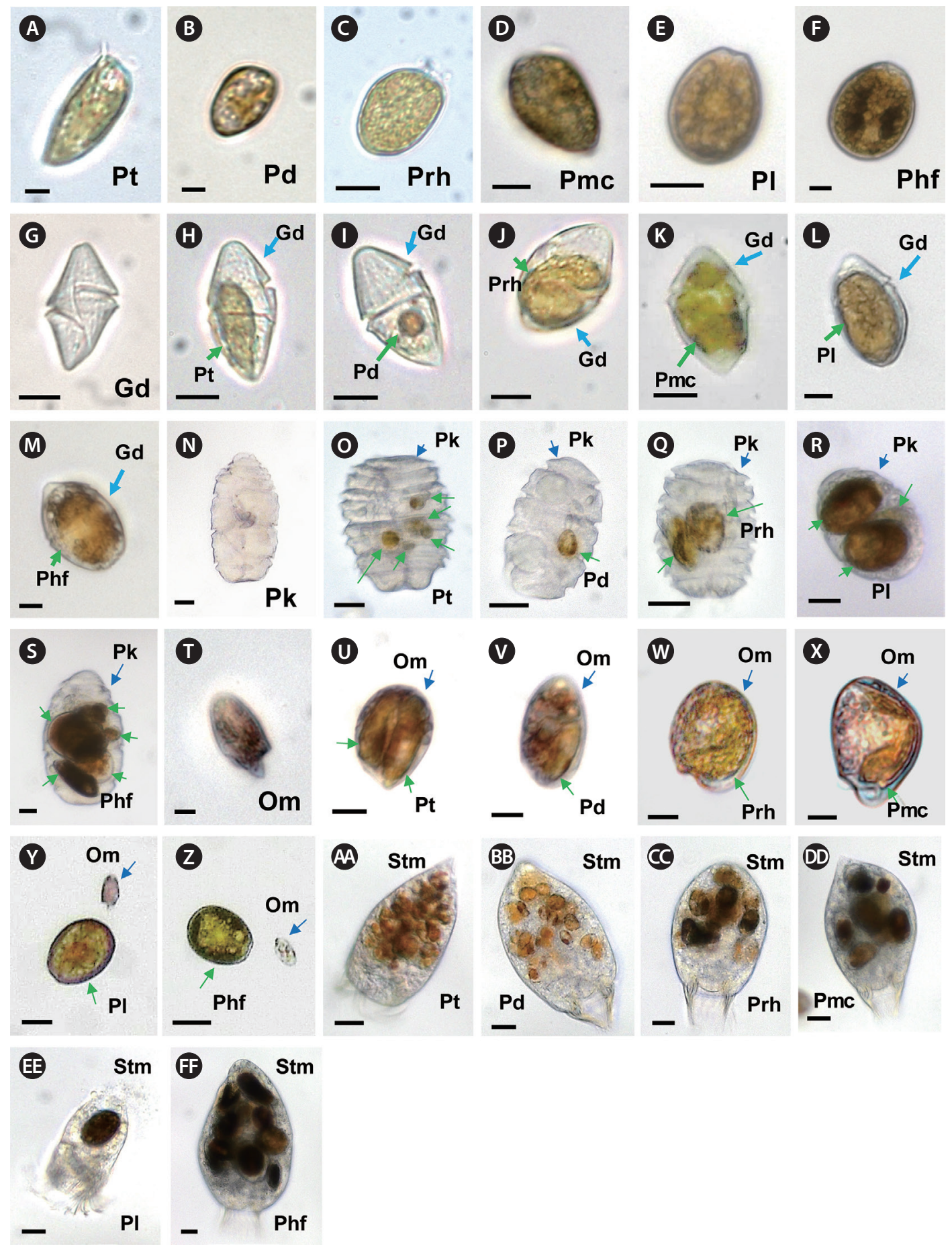

Fig. 1. Feeding by the heterotrophic dinoflagellates Gyrodinium dominans (Gd), Polykrikos kofoidii (Pk), and Oxyrrhis marina (Om) and the naked ciliate Strombidinopsis sp. (Stm; AA-FF) on Prorocentrum prey species (A-F). Intact Prorocentrum triestinum (Pt) (A), Prorocentrum donghaiense (Pd) (B), Prorocentrum rhathymum (Prh) (C), Prorocentrum micans (Pmc) (D), Prorocentrum lima (PI) (E), and Prorocentrum hoffmannianum (Phf) (F). Unfed Gd cell (G). Gd with an ingested Pt cell (H). Gd with an ingested Pd cell (I). Gd with an ingested Prh cell (J). Gd with an ingested Pmc cell (K). Gd with an ingested PI cell (L). Gd with an ingested Phf cell (M). Unfed Pk cell (N). Pk with five ingested Pt cells (O). Pk with an ingested Pd cell (P). Pk with two ingested Prh cells (Q). Pk with two ingested PI cells (R). Pk with five ingested Phf cells (S). Unfed Om cell (T). Om with two ingested Pt cells (U). Om with an ingested Pd cell (V). Om with an ingested Prh cell (W). Om with an ingested Pmc cell (X). Om did not feed on PI cell (Y). Om did not feed on Phf cell (Z). Stm with many ingested Pt cells (AA). Stm with many ingested Pd cells (BB). Stm with several ingested Prh cells (CC). Stm with several ingested Pmc cells (DD). Stm with an ingested PI cell (EE). Stm with several ingested Phf cells (FF). Scale bars represent: A \& B, $5 \mu$ m; C-M \& $\mathrm{T}-\mathrm{Z}, 10 \mu \mathrm{m} ; \mathrm{N}-\mathrm{S} \& \mathrm{AA}-\mathrm{FF}, 20 \mu \mathrm{m}$. 


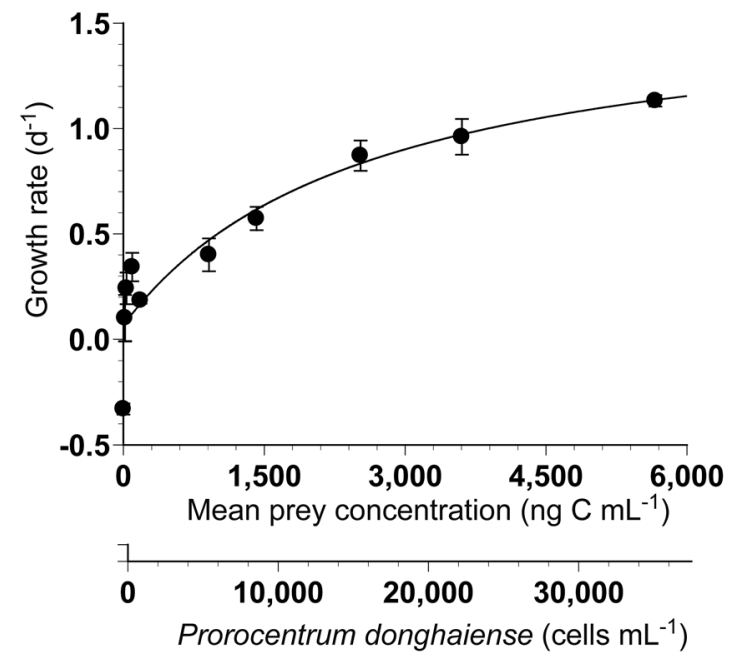

Fig. 2. Specific growth rate (GR) of Gyrodinium dominans on Prorocentrum donghaiense as a function of mean prey concentration $(x)$. Symbols represent treatment means \pm standard error. The curve is fitted according to a modified Michaelis-Menten equation [Eq. (2)] using all treatments in the experiment. GR $\left(d^{-1}\right)=1.62\{[x+92.5] /[2,510$ $+(x+92.5)]\}, r^{2}=0.866$.

\section{RESULTS}

\section{Feeding by heterotrophic protists on each Pro- rocentrum species}

All the heterotrophic protists tested were able to feed on P. triestinum, $P$. cordatum, $P$. donghaiense, $P$. rhathymum, and P. micans, although Pfiesteria piscicida was only able to feed on motionless prey cells (Fig. 1). Furthermore, Gyrodinium dominans, Polykrikos kofoidii, and Strombidinopsis sp. were able to feed on P. lima and $P$. hoffmannianum, and P. piscicida only on motionless prey cells (Fig. 1). However, Oxyrrhis marina did not feed on P. lima and P. hoffmannianum, although it did attempt to engulf them. Moreover, Oblea rotunda failed to deploy a pallium on P. lima and P. hoffmannianum, although it did anchor the cells using a tow filament.

\section{Growth and ingestion rates of Gyrodinium domi- nans on Prorocentrum donghaiense as a function of prey concentration}

The specific growth rates of G. dominans on P. donghaiense increased rapidly with increasing mean prey concentrations $<2,260 \mathrm{ng} \mathrm{C} \mathrm{mL}^{-1}\left(14,100\right.$ cells $\left.\mathrm{mL}^{-1}\right)$, but increased slowly at higher concentrations (Fig. 2). The specific growth rate of G. dominans without added prey was $-0.329 \mathrm{~d}^{-1}$. When the data were fitted to Eq. (2), the

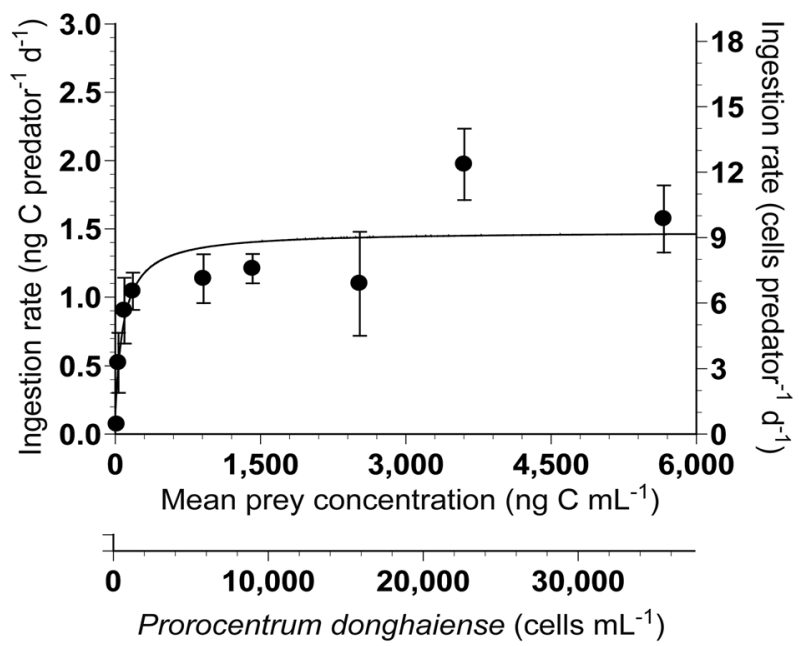

Fig. 3. Ingestion rate (IR) of Gyrodinium dominans on Prorocentrum donghaiense as a function of the mean prey concentration $(x)$. Symbols represent treatment means \pm standard error. The curve is fitted according to a modified Michaelis-Menten equation [Eq. (3)] using all treatments in the experiment. IR (ng C predator $\left.{ }^{-1} \mathrm{~d}^{-1}\right)=1.48\{[x] /[80.1$ $+(x)]\}, r^{2}=0.573$.

calculated maximum growth rate $\left(\mu_{\max }\right)$ of $G$. dominans on P. donghaiense was $1.62 \mathrm{~d}^{-1}$.

The ingestion rates of $G$. dominans on $P$. donghaiense increased rapidly with increasing mean prey concentrations $<155 \mathrm{ng} \mathrm{C} \mathrm{mL}^{-1}$ ( 970 cells $\mathrm{mL}^{-1}$ ), but became saturated at higher concentrations (Fig. 3). When the data were fitted to Eq. (3), the calculated maximum ingestion rate $\left(I_{\max }\right)$ of $G$. dominans on P. donghaiense was $1.48 \mathrm{ng} \mathrm{C}$ predator $^{-1} \mathrm{~d}^{-1}\left(9.3\right.$ cells predator $\left.{ }^{-1} \mathrm{~d}^{-1}\right)$. The $K_{\mathrm{IR}}$ was $80.1 \mathrm{ng}$ $\mathrm{C} \mathrm{mL}^{-1}$ (501 cells $\left.\mathrm{mL}^{-1}\right)$.

\section{Growth and ingestion rates of Gyrodinium domi- nans on all Prorocentrum spp. at single prey concentrations}

At single high mean prey concentrations of 2,450-2,779 ng C mL ${ }^{-1}$, the specific growth rates of G. dominans on $P$. donghaiense, P. triestinum, and P. cordatum were 0.871 , 0.850 , and $0.759 \mathrm{~d}^{-1}$, respectively; those on $P$. rhathymum, P. micans, and P. hoffmannianum were $0.499,0.206$, and $0.153 \mathrm{~d}^{-1}$, respectively, but that on P. lima was $-0.193 \mathrm{~d}^{-1}$ (Fig. 4A). The specific growth rates of G. dominans on the seven Prorocentrum spp. at single high mean prey concentrations were significantly different (ANOVA, $\mathrm{F}_{6,14}=$ 108.14, p < 0.001) (Fig. 4A), and Tukey's HSD test revealed that they were divided into four groups.

At single high mean prey concentrations of 2,450-2,779 ng C mL ${ }^{-1}$, the ingestion rates of G. dominans on P. rha- 

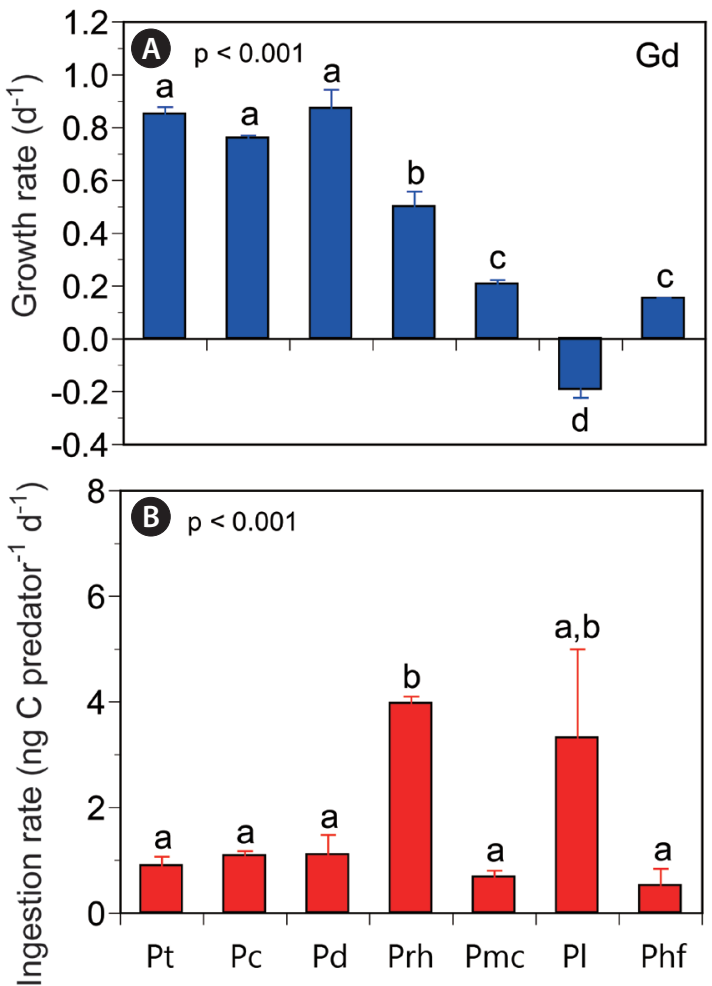

Fig. 4. Growth (A) and ingestion (B) rates of Gyrodinium dominans (Gd) on the seven Prorocentrum spp. at single high mean prey concentrations. Symbols represent treatment means \pm standard error. The different lowercase alphabetical letters above each bar indicate significantly different groups after post-hoc tests. Pt, Prorocentrum triestinum; Pc, Prorocentrum cordatum; Pd, Prorocentrum donghaiense; Prh, Prorocentrum rhathymum; Pmc, Prorocentrum micans; Pl, Prorocentrum lima; Phf, Prorocentrum hoffmannianum.

thymum and P. lima were 4.0 and $3.3 \mathrm{ng} \mathrm{C}$ predator ${ }^{-1} \mathrm{~d}^{-1}$, respectively, and those on $P$. donghaiense and $P$. cordatum were both $1.1 \mathrm{ng} \mathrm{C}$ predator ${ }^{-1} \mathrm{~d}^{-1}$; however, those on P. triestinum, P. micans, and P. hoffmannianum were 0.9 , 0.7 , and $0.5 \mathrm{ng} \mathrm{C}$ predator ${ }^{-1} \mathrm{~d}^{-1}$, respectively (Fig. 4B). The ingestion rates of G. dominans feeding on the seven Prorocentrum spp. were also significantly different (Welch's ANOVA, $\mathrm{F}_{6,6.08}=43.24, \mathrm{p}<0.001$ ) (Fig. 4B), and the GamesHowell post-hoc test revealed that they were divided into two groups.

The specific growth rates of G. dominans on the seven Prorocentrum spp. were significantly correlated with prey sizes (linear regression, F-test, $\mathrm{F}=69.46, \mathrm{r}^{2}=0.785$, $\mathrm{p}<0.001$ ), but the ingestion rates were not significantly correlated with prey sizes (linear regression, F-test, $\mathrm{F}=$ 0.59, $\mathrm{r}^{2}=0.030, \mathrm{p}=0.451$ ) (Fig. 5A \& B). Furthermore, the growth rates of $G$. dominans on the seven Prorocentrum spp. were not significantly correlated with the ingestion rates (linear regression, F-test, $\mathrm{F}=1.35, \mathrm{r}^{2}=0.066, \mathrm{p}=$ 0.261) (Fig. 5C).
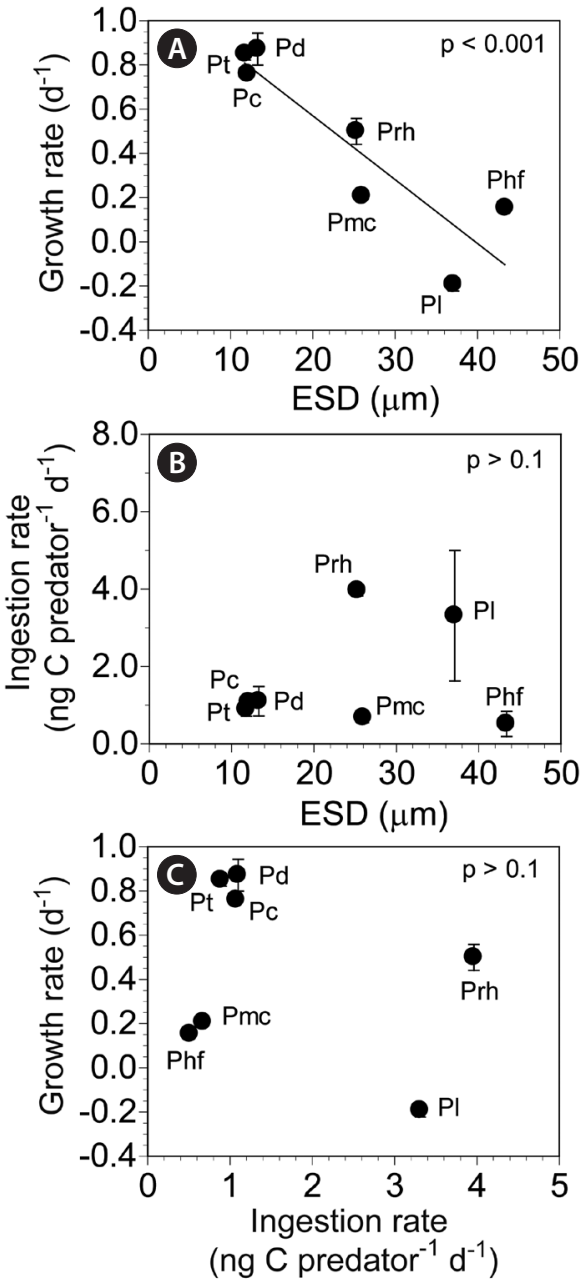

Fig. 5. Growth (GR) (A) and ingestion (B) rates of Gyrodinium dominans on seven Prorocentrum spp. as functions of prey size (ESD, $\mu$; equivalent spherical diameter). Growth rates of $G$. dominans on seven Prorocentrum prey species as functions of the ingestion rates $(C)$. The data were obtained from Fig. 4. Symbols represent treatment means \pm standard error. The equation of the linear regression in $(A)$ is as follows: $G R\left(d^{-1}\right)=-0.029$ (ESD) $+1.147, r^{2}=0.785$. Pc, Prorocentrum cordatum; Pd, Prorocentrum donghaiense; Phf, Prorocentrum hoffmannianum; Pl, Prorocentrum lima; Pmc, Prorocentrum micans; Prh, Prorocentrum rhathymum; Pt, Prorocentrum triestinum.

\section{Growth and ingestion rates of Polykrikos kofoidii on Prorocentrum hoffmannianum as a function of prey concentration}

The specific growth rates of $P$. kofoidii on P. hoffmannianum ranged from -0.325 to $0.165 \mathrm{~d}^{-1}$ (Fig. 6). The specific growth rates of $P$. kofoidii on $P$. hoffmannianum at mean prey concentrations of 4-577 $\mathrm{ng} \mathrm{C} \mathrm{mL}^{-1}$ (2-254 cells $\left.\mathrm{mL}^{-1}\right)$ were not significantly different from zero $(\mathrm{p}>0.1$, two-tailed $t$-test). However, the specific growth rate of P. kofoidii on P. hoffmannianum at $1,518 \mathrm{ng} \mathrm{C} \mathrm{mL}^{-1}$ (669 


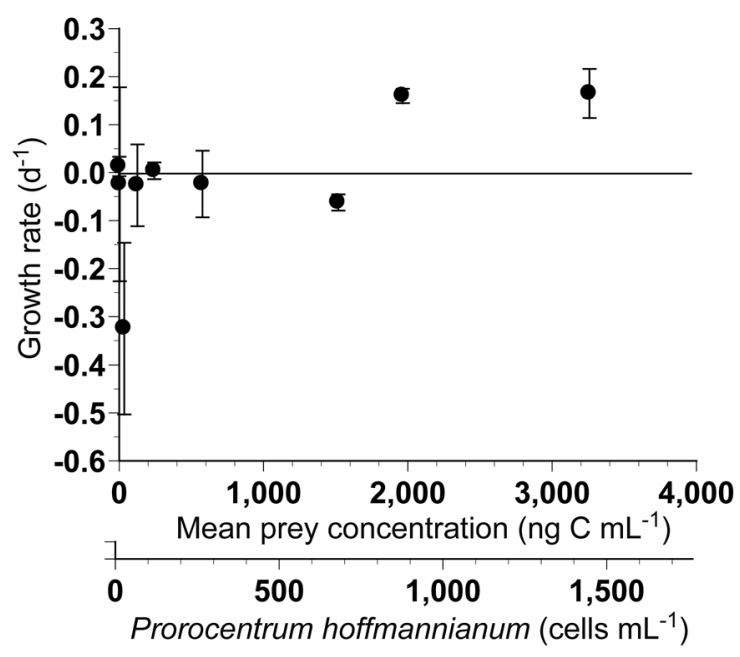

Fig. 6. Specific growth rate of Polykrikos kofoidii on Prorocentrum hoffmannianum as a function of the mean prey concentration $(x)$. Symbols represent treatment means \pm standard error.

cells $\mathrm{mL}^{-1}$ ) was significantly lower than zero $(\mathrm{p}<0.05$, one-tailed $t$-test), whereas those at 1,965-3,259 $\mathrm{ng} \mathrm{C} \mathrm{mL}^{-1}$ (866-1,436 cells $\mathrm{mL}^{-1}$ ) were significantly greater than zero ( $\mathrm{p}<0.05$ or $\mathrm{p}<0.005$, one-tailed $t$-test) (Fig. 6).

The ingestion rates of $P$. kofoidii on $P$. hoffmannianum ranged from 1.1 to $7.3 \mathrm{ng} C$ predator ${ }^{-1} \mathrm{~d}^{-1}$ (Fig. 7). The ingestion rates of $P$. kofoidii on $P$. hoffmannianum at mean prey concentrations of 4-126 ng C mL $\mathrm{m}^{-1}$ (2-55 cells $\left.\mathrm{mL}^{-1}\right)$ and 1,965-3,259 ng C mL $\mathrm{m}^{-1}$ (866-1,436 cells $\left.\mathrm{mL}^{-1}\right)$ were significantly greater than zero ( $\mathrm{p}<0.05$ or 0.01 , one-tailed $t$-test); however, the rest were not significantly different from zero at the other mean prey concentrations ( $\mathrm{p}>0.1$, two-tailed $t$-test).

\section{Growth and ingestion rates of Polykrikos kofoidii on all Prorocentrum spp. at single prey concen- trations}

At single high mean prey concentrations of 1,442-1,965 ng C mL ${ }^{-1}$, the specific growth rate of $P$. kofoidii on $P$. hoffmannianum was $0.160 \mathrm{~d}^{-1}$, but those on $P$. donghaiense, $P$. lima, . rhathymum, and $P$. triestinum ranged from -0.272 to $-0.071 \mathrm{~d}^{-1}$ (Fig. 8A). The specific growth rates of $P$. kofoidii on $P$. cordatum and $P$. micans at 1,467-2,303 $\mathrm{ng} \mathrm{C} \mathrm{mL}^{-1}$ were -0.363 and $-0.042 \mathrm{~d}^{-1}$, respectively (Kim and Jeong 2004). The specific growth rates of $P$. kofoidii on the seven Prorocentrum spp. at single high mean prey concentrations were significantly different (ANOVA, $\mathrm{F}_{6,14}=6.32, \mathrm{p}=$ 0.002) (Fig. 8A), and Tukey's HSD test revealed that they were divided into two groups.

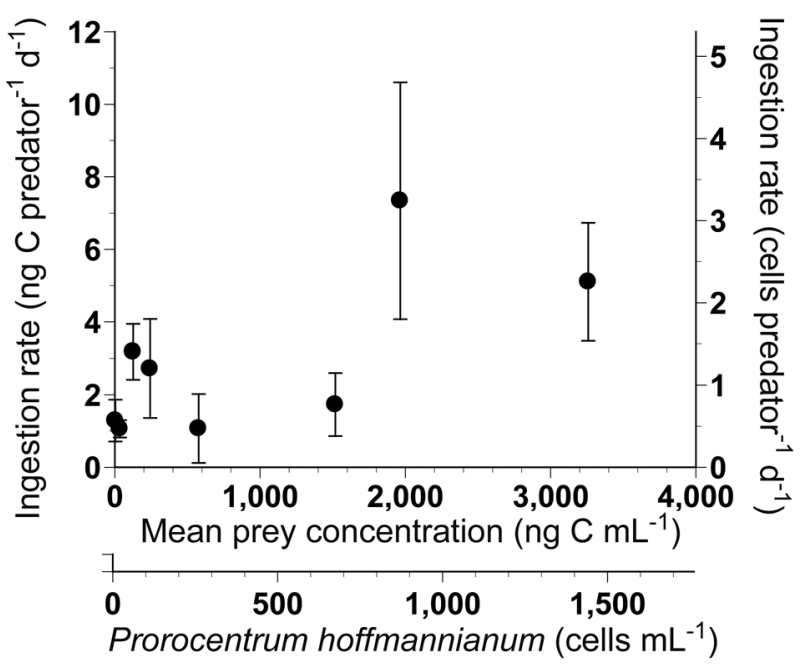

Fig. 7. Ingestion rate of Polykrikos kofoidii on Prorocentrum hoffmannianum as a function of the mean prey concentration $(x)$. Symbols represent treatment means \pm standard error.

At single high mean prey concentrations of 1,442-1,965 ng $\mathrm{C} \mathrm{mL}^{-1}$, the ingestion rate of $P$. kofoidii on $P$. hoffmannianum was $7.3 \mathrm{ng} \mathrm{C}$ predator ${ }^{-1} \mathrm{~d}^{-1}$, those on $P$. lima and P. rhathymum were 4.2-4.7 ng C predator ${ }^{-1} \mathrm{~d}^{-1}$, and those on $P$. donghaiense and $P$ triestinum were $0.8-1.0 \mathrm{ng} \mathrm{C}$ predator $^{-1} \mathrm{~d}^{-1}$ (Fig. 8B). The ingestion rates of $P$. kofoidii

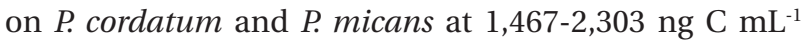
were 0.4 and $4.1 \mathrm{ng} \mathrm{C}$ predator ${ }^{-1} \mathrm{~d}^{-1}$, respectively (Kim and Jeong 2004). The ingestion rates of $P$. kofoidii on the seven Prorocentrum spp. at single high mean prey concentrations were significantly different (Kruskal-Wallis test, $H_{6}$ $=12.98, \mathrm{p}=0.043$ ) (Fig. 8B); however, they were not divided into different groups as per the Mann-Whitney $U$ test with Bonferroni correction.

The specific growth rates of $P$. kofoidii on the seven Prorocentrum spp. were significantly correlated with prey sizes (linear regression, F-test, $F=9.04, r^{2}=0.322$, $\mathrm{p}=0.007$ ), and the ingestion rates were also significantly correlated with prey sizes (linear regression, F-test, F = 18.74, $\mathrm{r}^{2}=0.497, \mathrm{p}<0.001$ ) (Fig. 9A \& B). Furthermore, the growth rates of $P$. kofoidii on the seven Prorocentrum spp. were significantly correlated with the ingestion rates (linear regression, F-test, $\mathrm{F}=8.31, \mathrm{r}^{2}=0.304, \mathrm{p}=0.010$ ) (Fig. 9C).

The specific growth rates of G. dominans and P. kofoidii were significantly differently affected by the seven Prorocentrum spp. at single high mean prey concentrations (MANOVA, Pillai's trace $=1.69, \mathrm{~F}_{12,28}=12.65, \mathrm{p}<0.001$ ). Moreover, the ingestion rates of G. dominans and P. kofoidii were significantly differently affected by the seven 

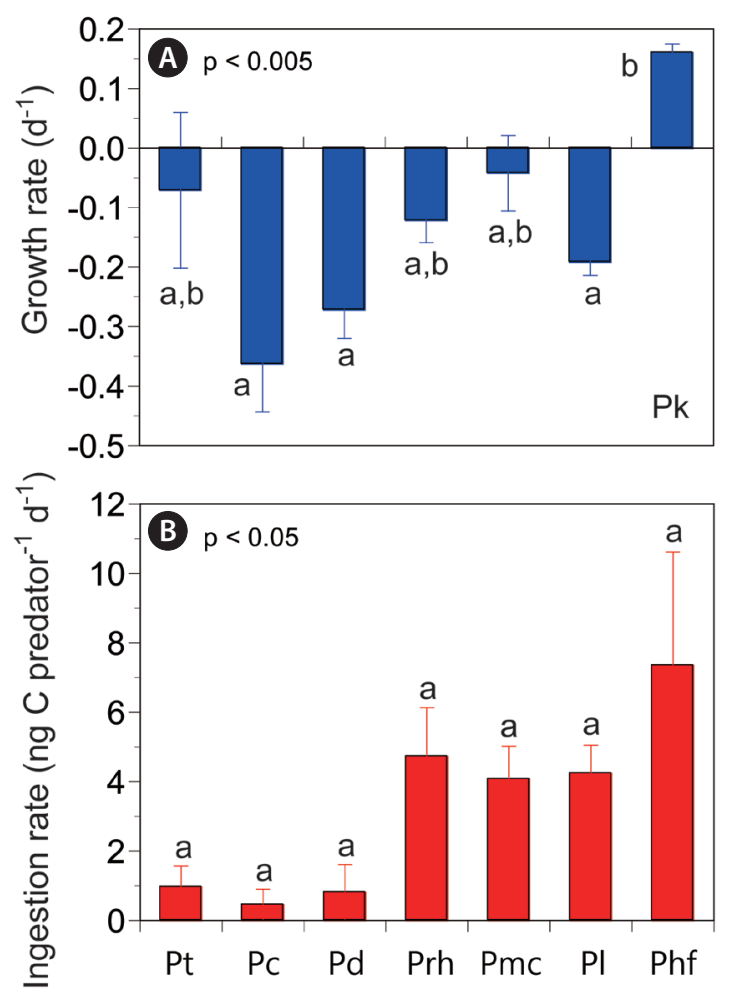

Fig. 8. Growth (A) and ingestion (B) rates of Polykrikos kofoidii (Pk) on the seven Prorocentrum spp. at single high mean prey concentrations. Symbols represent treatment means \pm standard error. The different lowercase alphabetical letters above each bar indicate significantly different groups after post-hoc tests. Pt, Prorocentrum triestinum; Pc, Prorocentrum cordatum; Pd, Prorocentrum donghaiense; Prh, Prorocentrum rhathymum; Pmc, Prorocentrum micans; Pl, Prorocentrum lima; Phf, Prorocentrum hoffmannianum.

Prorocentrum spp. at single high mean prey concentrations (MANOVA, Pillai's trace $=1.20, \mathrm{~F}_{12,28}=3.48, \mathrm{p}=0.003$ ).

\section{Swimming speed}

The average ( \pm standard error [SE], $\mathrm{n}=20$ ) and maximum swimming speeds of $P$. rhathymum, P. lima, and $P$. hoffmannianum were $254( \pm 18.43)$ and $420,78( \pm 6.47)$ and 160 , and $82( \pm 3.42)$ and $120 \mu \mathrm{m} \mathrm{s}^{-1}$, respectively.

The maximum swimming speeds of the seven Prorocentrum spp. were not significantly positively correlated with cell sizes (linear regression, F-test, $\mathrm{F}=0.261, \mathrm{r}^{2}=$ $0.050, \mathrm{p}=0.631$ ) when the data on the maximum swimming speeds of P. cordatum (194 $\left.\mu \mathrm{m} \mathrm{s}^{-1}\right)$, P. triestinum (175 $\left.\mu \mathrm{m} \mathrm{s}^{-1}\right)$, P. donghaiense $\left(280 \mu \mathrm{m} \mathrm{s}^{-1}\right)$, and P. micans $(380 \mu \mathrm{m}$ $\left.\mathrm{s}^{-1}\right)$ obtained from Jeong et al. $(1999 a, 2015)$ and Berdalet et al. (2007) were used.
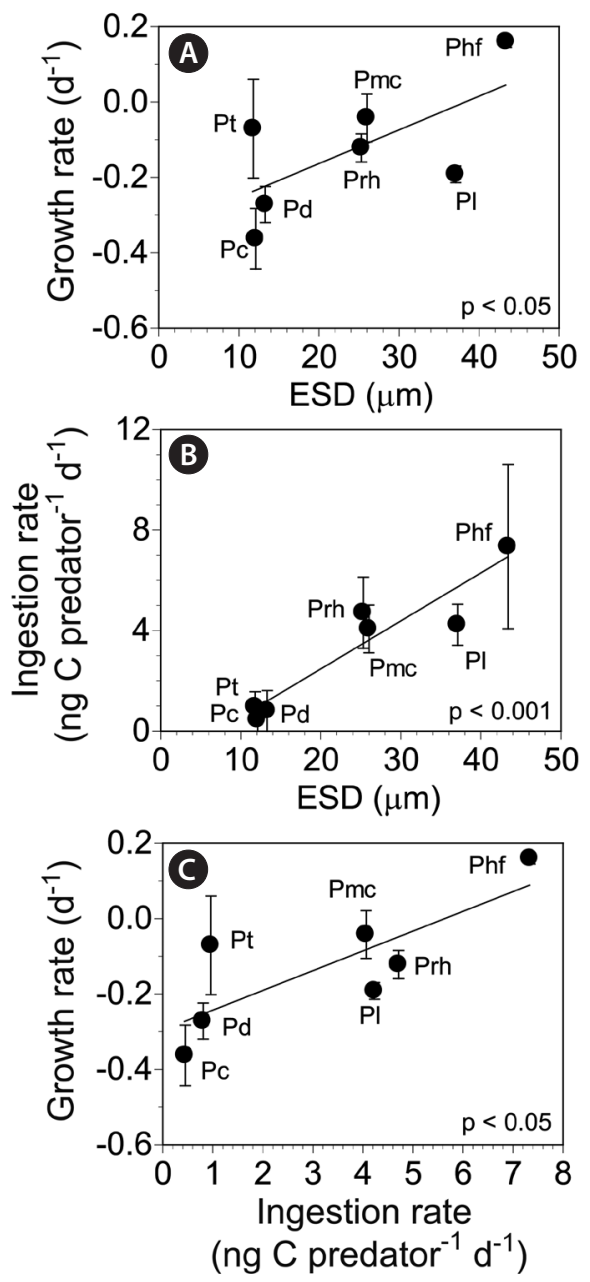

Fig. 9. Growth (GR) (A) and ingestion (B) rates of Polykrikos kofoidii on seven Prorocentrum spp. as functions of prey size (ESD, $\mu$ m; equivalent spherical diameter). Growth rates of $P$. kofoidii on seven Prorocentrum spp. as a function of the ingestion rates (IRs) (C). The data were obtained from Fig. 8. Symbols represent treatment means \pm standard error. The equations of the linear regressions are followings: (A) GR $\left(d^{-1}\right)=0.009$ (ESD) - 0.345, $r^{2}=0.322 ;(B)$ IR (ng C predator ${ }^{-1}$ $\left.d^{-1}\right)=0.191$ (ESD) - 1.389, $r^{2}=0.496 ;(C) G R\left(d^{-1}\right)=0.032\left(\right.$ IR) $-0.232, r^{2}$ $=0.307$. Pc, Prorocentrum cordatum; Pd, Prorocentrum donghaiense; Phf, Prorocentrum hoffmannianum; Pl, Prorocentrum lima; Pmc, Prorocentrum micans; Prh, Prorocentrum rhathymum; Pt, Prorocentrum triestinum.

\section{DISCUSSION}

\section{Feeding by heterotrophic protists on each Pro- rocentrum species}

The seven Prorocentrum spp. used in this study are known to cause red tides or algal blooms on the surface or bottom of water bodies (Labib 1996, Ismael and Aida 1997, Faust 2009, Ingarao et al. 2009, Li et al. 2011, Kang et al. 2013). Of these, Prorocentrum cordatum, P. micans, 
and $P$. triestinum have been reported to cause red tides in many countries, while $P$. donghaiense, $P$. rhathymum, $P$. hoffmannianum, and $P$. lima have been reported to cause red tides in only some countries (Labib 1996, Ismael and Aida 1997, Hajdu et al. 2000, Hernández-Becerril et al. 2000, Tango et al. 2005, Vila and Masó 2005, Faust 2009, Ingarao et al. 2009, Li et al. 2011, Kang et al. 2013, Jeong et al. 2017, Roselli et al. 2019). However, to understand the population dynamics of each of these species, their growth and mortality rates as a result of predation should be determined. To determine the mortality rate of each Prorocentrum sp. as a result of predation, the kind of predators should be first identified. We tested six heterotrophic protist predators that are commonly found in many marine environments; thus, there is a high possibility that any of these predators could encounter any of the seven Prorocentrum spp. Prior to this study, the type of heterotrophic protist predators that are able to feed on $P$. triestinum, $P$. rhathymum, and $P$. hoffmannianum had not been reported. This study showed that Gyrodinium dominans, Oxyrrhis marina, Oblea rotunda, Polykrikos kofoidii, and Strombidinopsis sp. are predators of $P$. triestinum and $P$. rhathymum, while G. dominans, P. kofoidii, and Strombidinopsis sp. are predators of $P$. hoffmannianum. Furthermore, Pfiesteria piscicida was able to feed on motionless cells of $P$. triestinum, $P$. rhathymum, and $P$. hoffmannianum, but not moving cells (Table 4).

Prior to this study, P. micans was reported to fed upon by G. dominans, O. rotunda, and P. kofoidii (Strom and Buskey 1993, Nakamura et al. 1995, Jeong et al. 2001b). Thus, this study extends the list of protist predators of P. micans to include O. marina and Strombidinopsis sp. Meanwhile, $P$. donghaiense was reported to be eaten by O. marina (An et al. 2016). Therefore, this study extends the list of protist predators of $P$. donghaiense to include G. dominans, O. rotunda, P. kofoidii, and Strombidinopsis sp. Lim et al. (2017) reported a high abundance of G. dominans following a red tide dominated by P. donghaiense in the South Sea of Korea in 2014. Thus, there is a high possibility that G. dominans fed actively on P. donghaiense in those waters. In addition, P. lima was reported to be eaten by $P$. kofoidii (Matsuoka et al. 2000). Thus, this study extends the list of protist predators of P. lima to include G. dominans and Strombidinopsis sp.

Based on their feeding on seven Prorocentrum spp., these six protist predator species can be categorized into three groups: the first group comprises $G$. dominans, $P$. kofoidii, and Strombidinopsis sp. that are able to feed on all seven Prorocentrum spp. (group I); the second group comprises O. marina and O. rotunda that are able to feed on some Prorocentrum spp., but not others (group II); and the third group comprises Pfiesteria piscicida that

Table 4. Feeding occurrence by six heterotrophic predators on each Prorocentrum sp.

\begin{tabular}{|c|c|c|c|c|c|c|c|c|c|c|}
\hline Prey species & Habitat & ESD & IPC & Om & Gd & Pk & $\mathrm{Pp}$ & Or & Stm & Reference \\
\hline $\begin{array}{l}\text { Prorocentrum } \\
\text { triestinum }\end{array}$ & PLK & 11.8 & $10-20$ & $\mathrm{O}$ & $\mathrm{O}$ & $\mathrm{O}$ & $\mathrm{O}^{\mathrm{b}}$ & $\mathrm{O}$ & $\mathrm{O}$ & This study \\
\hline P. cordatum & PLK & 12.1 & $10-20$ & $\mathrm{O}^{\mathrm{a}}$ & $\mathrm{O}^{\mathrm{a}}$ & $\mathrm{O}^{\mathrm{a}}$ & $\mathrm{O}^{\mathrm{b}}$ & $\mathrm{O}^{\mathrm{a}}$ & $\mathrm{O}^{\mathrm{a}}$ & $\begin{array}{l}\text { Strom and Buskey (1993), } \\
\text { Lee (1998), Jeong et al. } \\
(1999 b, 2001 b, 2006), \text { Kim } \\
\text { and Jeong }(2004), \text { This study }\end{array}$ \\
\hline P. donghaiense & PLK & 13.3 & $10-20$ & $\mathrm{O}^{\mathrm{a}}$ & $\mathrm{O}$ & $\mathrm{O}$ & $\mathrm{O}^{\mathrm{b}}$ & $\mathrm{O}$ & $\mathrm{O}$ & An et al. (2016), This study \\
\hline P. rhathymum & PLK & 25.3 & 5 & $\mathrm{O}$ & $\mathrm{O}$ & $\mathrm{O}$ & $\mathrm{O}^{\mathrm{b}}$ & $\mathrm{O}$ & $\mathrm{O}$ & This study \\
\hline P. micans & PLK & 26.6 & 5 & $\mathrm{O}$ & $\mathrm{O}^{\mathrm{a}}$ & $\mathrm{O}^{\mathrm{a}}$ & $\mathrm{O}^{\mathrm{b}}$ & $\mathrm{O}^{\mathrm{a}}$ & $\mathrm{O}$ & $\begin{array}{l}\text { Strom and Buskey (1993), } \\
\text { Nakamura et al. (1995), } \\
\text { Jeong et al. (2001b, 2006), } \\
\text { This study }\end{array}$ \\
\hline P. lima & BEN & 37.1 & 0.8 & $\mathrm{X}$ & $\mathrm{O}$ & $\mathrm{O}^{\mathrm{a}}$ & $\mathrm{O}^{\mathrm{b}}$ & $\mathrm{X}$ & $\mathrm{O}$ & $\begin{array}{l}\text { Matsuoka et al. (2000), } \\
\text { This study }\end{array}$ \\
\hline P. hoffmannianum & BEN & 43.4 & 0.8 & $\mathrm{X}$ & $\mathrm{O}$ & $\mathrm{O}$ & $\mathrm{O}^{\mathrm{b}}$ & $\mathrm{X}$ & $\mathrm{O}$ & This study \\
\hline
\end{tabular}

Initial predator concentrations (cells $\mathrm{mL}^{-1}$ ) were 1,000 for O. marina, 450-1,000 for G. dominans, 100 for P. kofoidii, 2,000 for P. piscicida, 300 for 0 . rotunda, and 5 for Strombidinopsis sp.

ESD, equivalent spherical diameter $(\mu \mathrm{m})$; IPC, target initial prey concentration ( $\times 10^{3}$ cells $\left.\mathrm{mL}^{-1}\right)$; Om, Oxyrrhis marina; Gd, Gyrodinium dominans; Pk, Polykrikos kofoidii; Pp, Pfiesteria piscicida; Or, Oblea rotunda; Stm, Strombidinopsis sp.; $\mathrm{O}$ or $\mathrm{O}^{\text {a }}$, the predator was observed to feed on the target prey cell; $\mathrm{X}$, the predator was not observed to feed on the target prey cell; $\mathrm{O}$ or $\mathrm{X}$, tested in this study; $\mathrm{O}^{\mathrm{a}}$, cited from other studies; $\mathrm{O}^{\mathrm{b}}$, the predator fed on motionless cells of the target Prorocentrum sp., but did not feed on moving cells. PLK, planktonic Prorocentrum spp.; BEN, benthic Prorocentrum spp. 
is able to feed on motionless cells of all seven Prorocentrum spp., but not moving cells (group III). G. dominans, Polykrikos kofoidii, and Strombidinopsis sp. succeeded in engulfing whole cells of the two largest Prorocentrum spp., P. lima and $P$. hoffmannianum, while $O$. marina tried (and failed) to engulf whole cells of these two Prorocentrum spp. In addition, $O$. rotunda failed to deploy a pallium although it did succeed in anchoring a prey cell using a tow filament. Thus, P. lima and P. hoffmannianum are likely too large for $O$. marina and $O$. rotunda to feed on. Moreover, Jeong et al. (2006) reported that Pfiesteria piscicida fed on naked dinoflagellates, but not on living cells of large mixotrophic thecate dinoflagellates of ESD $>12 \mu \mathrm{m}$. However, P. piscicida was able to feed on the dead cells of these large mixotrophic thecate dinoflagellates. Similarly, Kim et al. (2019) reported that P. piscicida did not feed on actively swimming cells of Scrippsiella acuminata (Ehrenberg) Kretschmann, Elbrächter, Zinssmeister, S. Soehner, Kirsch, Kusber \& Gottschling; S. lachrymosa J. Lewis ex Head; $S$. donghaiensis $\mathrm{H}$. Gu; and $S$. masanensis S. Y. Lee, H. J. Jeong, S. J. Kim, K. H. Lee \& S. $\mathrm{H}$. Jang, but did feed on motionless cells of these species. This study confirms this pattern of only feeding on the motionless cells of large thecate dinoflagellates. Meanwhile, P. piscicida did not feed on Yihiella yeosuensis $\mathrm{S}$. $\mathrm{H}$. Jang, H. J. Jeong, Ø. Moestrup \& N. S. Kang, although it is a naked dinoflagellate (Jeong et al. 2018). The fast jumping behavior of $Y$. yeosuensis was suggested to be responsible for P. piscicida not feeding, because heat-killed cells of $Y$. yeosuensis were consumed. P. piscicida only feeding on heat-killed prey cells was also found for the actively swimming heterotrophic nanoflagellate Katablepharis japonica N. Okamoto \& I. Inouye (Kim et al. 2017). Thus, with regard to feeding by $P$. piscicida, the presence and absence of thecate and fast and actively swimming behaviors in prey species are critical.

The maximum swimming speeds of $G$. dominans $\left(2,533 \mu \mathrm{m} \mathrm{s}^{-1}\right)$, O. marina $\left(700 \mu \mathrm{m} \mathrm{s}^{-1}\right)$, Pfiesteria piscicida $\left(670 \mu \mathrm{m} \mathrm{s}^{-1}\right)$, Polykrikos kofoidii $\left(911 \mu \mathrm{m} \mathrm{s}^{-1}\right)$, and Strombidinopsis sp. $\left(1,740 \mu \mathrm{m} \mathrm{s}^{-1}\right)$ are much greater than those of the seven Prorocentrum spp. (120-420 $\left.\mu_{\mathrm{m} \mathrm{s}}{ }^{-1}\right)$, although the maximum swimming speed of $O$. rotunda $\left(420 \mu \mathrm{m} \mathrm{s}^{-1}\right)$ is comparable to that of $P$. rhathymum, the fastest species among the seven Prorocentrum spp. (Cosson et al. 1988, Buskey et al. 1993, Burkholder and Glasgow 1997, Jeong et al. 1999a, 1999b, 2001b, 2002, Kim and Jeong 2004). Therefore, these predators may not have difficulty in catching any of these seven Prorocentrum prey species.

\section{Growth and ingestion rates of Gyrodinium domi- nans on Prorocentrum spp.}

At single high mean prey concentrations, all the Prorocentrum spp. tested in this study, except for $P$. lima, supported a positive growth rate of $G$. dominans. At single high mean prey concentrations, the growth rate of $G$. dominans on $P$. donghaiense was the highest $\left(0.871 \mathrm{~d}^{-1}\right)$, followed by $P$. triestinum and $P$. cordatum. The growth rates of G. dominans on the seven Prorocentrum spp. were significantly correlated with prey size. However, the growth rate of G. dominans on P. lima was negative, whereas that on the larger P. hoffmannianum was positive, although the size of $P$. lima $(37.1 \mu \mathrm{m})$ is smaller than that of $P$. hoffmannianum (43.4 $\mu \mathrm{m}$ ). Meanwhile, the ingestion rate of G. dominans on P. lima was considerably higher than that on P. hoffmannianum at similar mean prey concentrations. Both P. lima and P. hoffmannianum are known to produce diarrhetic shellfish poisoning toxins such as okadaic acid (OA) and OA analogs (dinophysis toxins) (e.g., Hu et al. 2010). In addition, they produce some polyketides without OA carbon framework; P. lima produces prorocentrolide and prorocentin, while $P$. hoffmannianum produces hoffmanniolide and prorocentrol (Torigoe et al. 1988, Hu et al. 1999, Lu et al. 2005, Sugahara et al. 2011). Thus, the prorocentrolide and prorocentin produced by $P$. lima may be partially responsible for this negative growth, whereas the hoffmanniolide and prorocentrol produced by $P$. hoffmannianum may not cause negative growth.

The calculated maximum growth rate $\left(\mu_{\max }\right)$ of G. dominans on P. donghaiense, when the data were fitted to Eq. (2), was $1.62 \mathrm{~d}^{-1}$, whereas the highest growth rate at the given prey concentration was $1.13 \mathrm{~d}^{-1}$ because the growth rates increased slowly but continuously. In the study of Kim and Jeong (2004), the calculated $\mu_{\max }$ of G. dominans on $P$. cordatum and the highest growth rate at the given prey concentration were both $1.13 \mathrm{~d}^{-1}$. Furthermore, at the single high prey concentration, the growth rate of $G$. dominans on P. donghaiense was slightly higher than that on $P$. cordatum. Thus, $P$. donghaiense may be the optimal Prorocentrum prey species for $G$. dominans, or at least be equally optimal to $P$. cordatum. Moreover, the calculated $\mu_{\max }$ of $G$. dominans on P. donghaiense is greater than that on any other algal prey species (Nakamura et al. 1995, Kim and Jeong 2004, Yoo et al. 2010, Jeong et al. 2011, 2014, Lee et al. 2014, Anderson and Menden-Deuer 2017, Kim et al. 2019). The abundance of G. dominans is expected to be high during or after red tides dominated by $P$. donghaiense. 


\section{Growth and ingestion rates of Polykrikos kofoidii on Prorocentrum spp.}

At single high mean prey concentrations, $P$. hoffmannianum supported the positive growth of $P$. kofoidii, but the six other Prorocentrum spp. caused negative growth. The ingestion rate of $P$. kofoidii on $P$. hoffmannianum was 7.3 ng C predator ${ }^{-1} \mathrm{~d}^{-1}$. Thus, a $P$. kofoidii cell acquired $174 \%$ of its own body carbon from $P$. hoffmannianum daily. The ingestion rates of $P$. kofoidii on $P$. rhathymum, P. lima, and P. micans were 4.1-4.7 ng C predator ${ }^{-1} \mathrm{~d}^{-1}$. Thus, a $P$. kofoidii cell acquired $98-112 \%$ of its own body carbon from P. rhathymum, P. lima, and P. micans daily. Differences in the ingestion rates between $P$. hoffmannianum and these three other Prorocentrum spp. may be responsible for the positive and negative growth rates of P. kofoidii. P. hoffmannianum is known to live attached to macroalgae or floating detritus (Faust 1990, 2009). Strong winds may detach $P$. hoffmannianum cells, allowing $P$. kofoidii to encounter them in the water column (Faust 2009). These detached $P$. hoffmannianum cells can be an excellent prey item for $P$. kofoidii.

The highest growth rate of P. kofoidii on P. hoffmannianum at the mean prey concentration given in this study $\left(0.165 \mathrm{~d}^{-1}\right)$ was slightly higher than those of the phototrophic dinoflagellates Effrenium voratum (H. J. Jeong, S. Y. Lee, N. S. Kang \& LaJeunesse) LaJeunesse \& H. J. Jeong, Gymnodinium impudicum (S. Fraga \& I. Bravo) Gert Hansen \& Moestrup, Amphidinium carterae, and Gymnodinium aureolum (E. M. Hulburt) Gert Hansen (0.04$0.11 \mathrm{~d}^{-1}$ ), but much lower than the $\mu_{\max }$ of P. kofoidii on Alexandrium tamarense (Lebour) Balech, Gymnodinium catenatum $\mathrm{H}$. W. Graham, Lingulodinium polyedra (F. Stein) J. D. Dodge, and Scrippsiella acuminata (0.83-1.12 $\mathrm{d}^{-1}$ ) (Jeong et al. 2001b, 2013, 2014, Yoo et al. 2010, Kang et al. 2018). The highest ingestion rate of $P$. kofoidii on $P$. hoffmannianum at the mean prey concentration given in this study (7.3 ng C predator ${ }^{-1} \mathrm{~d}^{-1}$ ) is lower than those on A. tamarense, G. catenatum, L. polyedra, and S. acuminata (16.6-26.2 ng C predator ${ }^{-1} \mathrm{~d}^{-1}$ ) (Jeong et al. 2001b, Kang et al. 2018). Thus, the low ingestion rate of $P$. kofoidii on $P$. hoffmannianum is partially responsible for its lower growth rate on the prey than those on the common redtide dinoflagellates A. tamarense, G. catenatum, L. polye$d r a$, and S. acuminata.

Conclusively, among the seven Prorocentrum spp., G. dominans showed the top three highest growth rates when it fed on the three smallest Prorocentrum spp., which were P. triestinum, P. cordatum, and P.donghaiense; however, $P$. kofoidii had negative growth rates when fed on these three prey species. Thus, during red tides dominated by $P$. triestinum, P. cordatum, and P. donghaiense, $G$. dominans is likely to be abundant, while $P$. kofoidii may be rare or absent. In contrast, $P$. kofoidii had a positive growth rate only when fed on $P$. hoffmannianum. Thus, when $P$. hoffmannianum is abundant, $P$. kofoidii may cooccur and G. dominans may be absent. This differential feeding on Prorocentrum spp. between G. dominans and $P$. kofoidii may provide different ecological niches and reduce competition between these two common heterotrophic protist predators.

\section{ACKNOWLEDGEMENTS}

We thank Sung Yeon Lee, Kyung Ha Lee, Se Hyeon Jang, Soo Yoon Kim, and Se Hee Eom for technical supports. This research was supported by the Useful Dinoflagellate program of Korea Institute of Marine Science and Technology Promotion (KIMST) funded by the Ministry of Oceans and Fisheries (MOF) and the National Research Foundation (NRF) funded by the Ministry of Science and ICT (NRF-2015M1A5A1041806; NRF2017R1E1A1A01074419) award to HJJ.

\section{REFERENCES}

An, X., Li, X. \& Li, Z. 2016. Effects of concentrations of Prorocentrum donghaiense and Oxyrrhis marina on the feeding behaviour of Oithona brevicornis. Nat. Environ. Pollut. Technol. 15:1195-1198.

Anderson, S. R. \& Menden-Deuer, S. 2017. Growth, grazing, and starvation survival in three heterotrophic dinoflagellate species. J. Eukaryot. Microbiol. 64:213-225.

Azanza, R. V., Fukuyo, Y., Yap, L. G. \& Takayama, H. 2005. Prorocentrum minimum bloom and its possible link to a massive fish kill in Bolinao, Pangasinan, Northern Philippines. Harmful Algae 4:519-524.

Backer, L. C. \& McGillicuddy, D. J. Jr. 2006. Harmful algal blooms: at the interface between coastal oceanography and human health. Oceanography 19:94-106.

Barker, H. A. 1935. The culture and physiology of the marine dinoflagellates. Arch. Mikrobiol. 6:157-181.

Berdalet, E., Peters, F., Koumandou, V. L., Roldán, C., Guadayol, Ò. \& Estrada, M. 2007. Species-specific physiological response of dinoflagellates to quantified smallscale turbulence. J. Phycol. 43:965-977.

Burkholder, J. M. \& Glasgow, H. B. Jr. 1997. Pfiesteria piscicida and other Pfiesreria-like dinoflagellates: behavior, 
impacts, and environmental controls. Limnol. Oceanogr. 42:1052-1075.

Buskey, E. J., Coulter, C. \& Strom, S. 1993. Locomotory patterns of microzooplankton: potential effects on food selectivity of larval fish. Bull. Mar. Sci. 53:29-43.

Calbet, A., Isari, S., Martínez, R. A., Saiz, E., Garrido, S., Peters, J., Borrat, R. M. \& Alcaraz, M. 2013. Adaptations to feast and famine in different strains of the marine heterotrophic dinoflagellates Gyrodinium dominans and Oxyrrhis marina. Mar. Ecol. Prog. Ser. 483:67-84.

Chen, H. L., Lu, S. H., Zhang, C. S. \& Zhu, D. D. 2006. A survey on the red tide of Prorocentrum donghaiense in East China Sea, 2004. Ecol. Sci. 25:226-230.

Claessens, M., Wickham, S. A., Post, A. F. \& Reuter, M. 2008. Ciliate community in the oligotrophic Gulf of Aqaba, Red Sea. Aquat. Microb. Ecol. 53:181-190.

Cosson, J., Cachon, M., Cachon, J. \& Cosson, M. -P. 1988. Swimming behaviour of the unicellular biflagellate $O x$ yrrhis marina: in vivo and in vitro movement of the two flagella. Biol. Cell 63:117-126.

Coyne, K. J., Hutchins, D. A., Hare, C. E. \& Cary, S. C. 2001. Assessing temporal and spatial variability in Pfiesteria piscicida distributions using molecular probing techniques. Aquat. Microb. Ecol. 24:275-285.

Dam, H. G. \& Colin, S. P. 2005. Prorocentrum minimum (clone Exuv) is nutritionally insufficient, but not toxic to the copepod Acartia tonsa. Harmful Algae 4:575-584.

Faust, M. A. 1990. Morphologic details of six benthic species of Prorocentrum (Pyrrophyta) from a mangrove island, twin cays, belize, including two new species. J. Phycol. 26:548-558.

Faust, M. A. 2009. Ciguatera-causing dinoflagellates in a coral-reef mangrove ecosystem, Belize. Atoll Res. Bull. 569:1-30.

Franklin, D. J., Brussaard, C. P. D. \& Berges, J. A. 2006. What is the role and nature of programmed cell death in phytoplankton ecology? Eur. J. Phycol. 41:1-14.

Frost, B. W. 1972. Effects of size and concentration of food particles on the feeding behavior of the marine planktonic copepod Calanus pacificus. Limnol. Oceanogr. 17:805-815.

Gaines, G. \& Taylor, F. J. R. 1984. Extracellular digestion in marine dinoflagellates. J. Plankton Res. 6:1057-1061.

Guillard, R. R. L. \& Hargraves, P. E. 1993. Stichochrysis immobilis is a diatom, not a chrysophyte. Phycologia 32:234236.

Guillard, R. R. L. \& Ryther, J. H. 1962. Studies of marine planktonic diatoms: I. Cyclotella nana Hustedt, and Detonula confervacea (Cleve) Gran. Can. J. Microbiol. 8:229-239.

Hajdu, S., Edler, L., Olenina, I. \& Witek, B. 2000. Spreading and establishment of the potentially toxic dinoflagellate Prorocentrum minimum in the Baltic Sea. Int. Rev. Hydrobiol. 85:561-575.

Hallegraeff, G. M. 1992. Harmful algal blooms in the Australian region. Mar. Pollut. Bull. 25:186-190.

Hansen, P. J. 1991. Quantitative importance and trophic role of heterotrophic dinoflagellates in a coastal pelagial food web. Mar. Ecol. Prog. Ser. 73:253-261.

Hansen, P. J. 1992. Prey size selection, feeding rates and growth dynamics of heterotrophic dinoflagellates with special emphasis on Gyrodinium spirale. Mar. Biol. 114:327-334.

Heil, C. A., Glibert, P. M. \& Fan, C. 2005. Prorocentrum minimum (Pavillard) Schiller: a review of a harmful algal bloom species of growing worldwide importance. Harmful Algae 4:449-470.

Heinbokel, J. F. 1978. Studies on the functional role of tintinnids in the Southern California Bight. I. Grazing and growth rates in laboratory cultures. Mar. Biol. 47:177189.

Hernández-Becerril, D. U., Altamirano, R. C. \& Alonso, R. R. 2000. The dinoflagellate genus Prorocentrum along the coasts of the Mexican Pacific. Hydrobiologia 418:111121.

Hoppenrath, M., Chomérat, N., Horiguchi, T., Schweikert, M., Nagahama, Y. \& Murray, S. 2013. Taxonomy and phylogeny of the benthic Prorocentrum species (Dinophyceae): a proposal and review. Harmful Algae 27:1-28.

Hu, T., Curtis, J. M., Walter, J. A. \& Wright, J. L. C. 1999. Hoffmanniolide: a novel macrolide from Prorocentrum hoffmannianum. Tetrahedron Lett. 40:3977-3980.

Hu, W., Xu, J., Sinkkonen, J. \& Wu, J. 2010. Polyketides from marine dinoflagellates of the genus Prorocentrum, biosynthetic origin and bioactivity of their okadaic acid analogues. Mini-Rev. Med. Chem. 10:51-61.

Ingarao, C., Lanciani, G., Verri, C. \& Pagliani, T. 2009. First record of Prorocentrum lima (Dinophyceae) inside harbor areas and along the Abruzzo region coast, W Adriatic. Mar. Pollut. Bull. 58:596-600.

Ismael, G. I. \& Aida, M. L. 1997. First record of a Prorocentrum rhathymum (Prorocentraceae) red tide in the Gulf of California. Rev. Biol. Trop. 45:1263-1271.

Jeong, H. J., Ha, J. H., Park, J. Y., Kim, J. H., Kang, N. S., Kim, S., Kim, J. S., Yoo, Y. D. \& Yih, W. H. 2006. Distribution of the heterotrophic dinoflagellate Pfiesteria piscicida in Korean waters and its consumption of mixotrophic dinoflagellates, raphidophytes and fish blood cells. Aquat. Microb. Ecol. 44:263-278.

Jeong, H. J., Kang, H., Shim, J. H., Park, J. K., Kim, J. S., Song, J. Y. \& Choi, H. -J. 2001a. Interactions among the toxic 
dinoflagellate Amphidinium carterae, the heterotrophic dinoflagellate Oxyrrhis marina, and the calanoid copepods Acartia spp. Mar. Ecol. Prog. Ser. 218:77-86.

Jeong, H. J., Kang, H. C., You, J. H. \& Jang, S. H. 2018. Interactions between the newly described small- and fastswimming mixotrophic dinoflagellate Yihiella yeosuensis and common heterotrophic protists. J. Eukaryot. Microbiol. 65:612-626.

Jeong, H. J., Kim, J. S., Song, J. Y., Kim, J. H., Kim, T. H., Kim, S. K. \& Kang, N. S. 2007. Feeding by protists and copepods on the heterotrophic dinoflagellates Pfiesteria piscicida, Stoeckeria algicida, and Luciella masanensis. Mar. Ecol. Prog. Ser. 349:199-211.

Jeong, H. J., Kim, S. K., Kim, J. S., Kim, S. T., Yoo, Y. D. \& Yoon, J. Y. 2001b. Growth and grazing rates of the heterotrophic dinoflagellate Polykrikos kofoidii on red-tide and toxic dinoflagellates. J. Eukaryot. Microbiol. 48:298-308.

Jeong, H. J., Kim, T. H., Yoo, Y. D., Yoon, E. Y., Kim, J. S., Seong, K. A., Kim, K. Y. \& Park, J. Y. 2011. Grazing impact of heterotrophic dinoflagellates and ciliates on common redtide euglenophyte Eutreptiella gymnastica in Masan Bay, Korea. Harmful Algae 10:576-588.

Jeong, H. J., Lim, A. S., Franks, P. J. S., Lee, K. H., Kim, J. H., Kang, N. S., Lee, M. J., Jang, S. H., Lee, S. Y., Yoon, E. Y., Park, J. Y., Yoo, Y. D., Seong, K. A., Kwon, J. E. \& Jang, T. Y. 2015. A hierarchy of conceptual models of red-tide generation: nutrition, behavior, and biological interactions. Harmful Algae 47:97-115.

Jeong, H. J., Lim, A. S., Lee, K., Lee, M. J., Seong, K. A., Kang, N. S., Jang, S. H., Lee, K. H., Lee, S. Y., Kim, M. O., Kim, J. H., Kwon, J. E., Kang, H. C., Kim, J. S., Yih, W., Shin, K., Jang, P. K., Ryu, J. -H., Kim, S. Y., Park, J. Y. \& Kim, K. Y. 2017. Ichthyotoxic Cochlodinium polykrikoides red tides offshore in the South Sea, Korea in 2014: I. Temporal variations in three-dimensional distributions of red-tide organisms and environmental factors. Algae 32:101-130.

Jeong, H. J., Lim, A. S., Yoo, Y. D., Lee, M. J., Lee, K. H., Jang, T. Y. \& Lee, K. 2014. Feeding by heterotrophic dinoflagellates and ciliates on the free-living dinoflagellate Symbiodinium sp. (Clade E). J. Eukaryot. Microbiol. 61:27-41.

Jeong, H. J., Shim, J. H., Kim, J. S., Park, J. Y., Lee, C. W. \& Lee, Y. 1999a. Feeding by the mixotrophic thecate dinoflagellate Fragilidium cf. mexicanum on red-tide and toxic dinoflagellates. Mar. Ecol. Prog. Ser. 176:263-277.

Jeong, H. J., Shim, J. H., Lee, C. W., Kim, J. S. \& Koh, S. M. $1999 \mathrm{~b}$. Growth and grazing rates of the marine planktonic ciliate Strombidinopsis sp. on red-tide and toxic dinoflagellates. J. Eukaryot. Microbiol. 46:69-76.

Jeong, H. J., Yoo, Y. D., Kim, J. S., Seong, K. A., Kang, N. S. \&
Kim, T. H. 2010. Growth, feeding and ecological roles of the mixotrophic and heterotrophic dinoflagellates in marine planktonic food webs. Ocean Sci. J. 45:65-91.

Jeong, H. J., Yoo, Y. D., Lee, K. H., Kim, T. H., Seong, K. A., Kang, N. S., Lee, S. Y., Kim, J. S., Kim, S. \&Yih, W. H. 2013. Red tides in Masan Bay, Korea in 2004-2005: I. Daily variations in the abundance of red-tide organisms and environmental factors. Harmful Algae 30(Supp. 1):S75S88.

Jeong, H. J., Yoon, J. Y., Kim, J. S., Yoo, Y. D. \& Seong, K. A. 2002. Growth and grazing rates of the prostomatid ciliate Tiarina fusus on red-tide and toxic algae. Aquat. Microb. Ecol. 28:289-297.

Kang, H. C., Jeong, H. J., Jang, S. H. \& Lee, K. H. 2019. Feeding by common heterotrophic protists on the phototrophic dinoflagellate Biecheleriopsis adriatica (Suessiaceae) compared to that of other suessioid dinoflagellates. Algae 34:127-140.

Kang, H. C., Jeong, H. J., Kim, S. J., You, J. H. \& Ok, J. H. 2018. Differential feeding by common heterotrophic protists on 12 different Alexandrium species. Harmful Algae 78:106-117.

Kang, N. S., Lee, K. H., Jeong, H. J., Yoo, Y. D., Seong, K. A., Potvin, E., Hwang, Y. J. \& Yoon, E. Y. 2013. Red tides in Shiwha Bay, western Korea: a huge dike and tidal power plant established in a semi-enclosed embayment system. Harmful Algae 30(Suppl. 1):S114-S130.

Khan, S., Arakawa, O. \& Onoue, Y. 1997. Neurotoxins in a toxic red tide of Heterosigma akashiwo (Raphidophyceae) in Kagoshima Bay, Japan. Aquac. Res. 28:9-14.

Kim, J. S. \& Jeong, H. J. 2004. Feeding by the heterotrophic dinoflagellates Gyrodinium dominans and G. spirale on the red-tide dinoflagellate Prorocentrum minimum. Mar. Ecol. Prog. Ser. 280:85-94.

Kim, S. J., Jeong, H. J., Jang, S. H., Lee, S. Y. \& Park, T. G. 2017. Interactions between the voracious heterotrophic nanoflagellate Katablepharis japonica and common heterotrophic protists. Algae 32:309-324.

Kim, S. J., Jeong, H. J., Kang, H. C., You, J. H. \& Ok, J. H. 2019. Differential feeding by common heterotrophic protists on four Scrippsiella species of similar size. J. Phycol. 55:868-881.

Kudela, R. M. \& Gobler, C. J. 2012. Harmful dinoflagellate blooms caused by Cochlodinium sp.: global expansion and ecological strategies facilitating bloom formation. Harmful Algae 14:71-86.

Labib, W. 1996. Water discoloration in Alexandria, Egypt, April 1993. I. Occurrence of Prorocentrum triestinum Schiffer (red tide) bloom and associated physical and chemical conditions. Chem. Ecol. 12:163-170. 
Lee, C. W. 1998. Growth and grazing rates of the heterotrophic dinoflagellate Oxyrrhis marina and the ciliate Stormbidinopsis sp. on Prorocentrum spp. M.S. thesis, Kunsan National University, Gunsan, 36 pp. (in Korean with English abstract).

Lee, K. H., Jeong, H. J., Kang, H. C., Ok, J. H., You, J. H. \& Park, S. A. 2019a. Growth rates and nitrate uptake of cooccurring red-tide dinoflagellates Alexandrium affine and $A$. fraterculus as a function of nitrate concentration under light-dark and continuous light conditions. Algae 34:237-251.

Lee, K. H., Jeong, H. J., Yoon, E. Y., Jang, S. H., Kim, H. S. \& Yih, W. 2014. Feeding by common heterotrophic dinoflagellates and a ciliate on the red-tide ciliate Mesodinium rubrum. Algae 29:153-163.

Lee, S. Y., Jeong, H. J., Kwon, J. E., You, J. H., Kim, S. J., Ok, J. H., Kang, H. C. \& Park, J. Y. 2019b. First report of the photosynthetic dinoflagellate Heterocapsa minima in the Pacific Ocean: morphological and genetic characterizations and the nationwide distribution in Korea. Algae 34:7-21.

Lee, S. Y., Jeong, H. J., You, J. H. \& Kim, S. J. 2018. Morphological and genetic characterization and the nationwide distribution of the phototrophic dinoflagellate Scrippsiella lachrymosa in the Korean waters. Algae 33:21-35.

Leles, S. G., Mitra, A., Flynn, K. J., Tillmann, U., Stoecker, D., Jeong, H. J., Burkholder, J., Hansen, P. J., Caron, D., Glibert, P., Hallegraef, G., Raven, J. A., Sanders, R. W. \& Zubkov, M. 2019. Sampling bias misrepresents the biogeographical significance of constitutive mixotrophs across global oceans. Glob. Ecol. Biogeogr. 28:418-428.

Lewis, J. 1990. The cyst-theca relationship of Oblea rotunda (Diplopsalidaceae, Dinophyceae). Br. Phycol. J. 25:339351.

Li, Y., Lü, S., Jiang, T., Xiao, Y. \& You, S. 2011. Environmental factors and seasonal dynamics of Prorocentrum populations in Nanji Islands National Nature Reserve, East China Sea. Harmful Algae 10:426-432.

Lim, A. S., Jeong, H. J., Jang, T. Y., Kang, N. S., Lee, S. Y., Yoo, Y. D. \& Kim, H. S. 2013. Morphology and molecular characterization of the epiphytic dinoflagellate Prorocentrum cf. rhathymum in temperate waters off Jeju Island, Korea. Ocean Sci. J. 48:1-17.

Lim, A. S., Jeong, H. J., Seong, K. A., Lee, M. J., Kang, N. S., Jang, S. H., Lee, K. H., Park, J. Y., Jang, T. Y. \& Yoo, Y. D. 2017. Ichthyotoxic Cochlodinium polykrikoides red tides offshore in the South Sea, Korea in 2014: II. Heterotrophic protists and their grazing impacts on redtide organisms. Algae 32:199-222.

Lowe, C. D., Day, A., Kemp, S. J. \& Montagnes, D. J. S. 2005.
There are high levels of functional and genetic diversity in Oxyrrhis marina. J. Eukaryot. Microbiol. 52:250-257.

Lu, C. K., Chou, H. N., Lee, C. K. \& Li, Z. -H. 2005. Prorocentin, a new polyketide from the marine dinoflagellate Prorocentrum lima. Org. Lett. 7:3893-3896.

Mallin, M. A., Paerl, H. W. \& Rudek, J. 1991. Seasonal phytoplankton composition, productivity and biomass in the Neuse River estuary, North Carolina. Estuar. Coast. Shelf Sci. 32:609-623.

Matsubara, T., Nagasoe, S., Yamasaki, Y., Shikata, T., Shimasaki, Y., Oshima, Y. \& Honjo, T. 2007. Effects of temperature, salinity, and irradiance on the growth of the dinoflagellate Akashiwo sanguinea. J. Exp. Mar. Biol. Ecol. 342:226-230

Matsuoka, K., Cho, H. -J. \& Jacobson, D. M. 2000. Observations of the feeding behavior and growth rates of the heterotrophic dinoflagellate Polykrikos kofoidii (Polykrikaceae, Dinophyceae). Phycologia 39:82-86.

Morton, S. L., Bomber, J. W. \& Tindall, P. M. 1994. Environmental effects on the production of okadaic acid from Prorocentrum hoffmannianum Faust I. temperature, light, and salinity. J. Exp. Mar. Biol. Ecol. 178:67-77.

Murakami, Y., Oshima, Y. \& Yasumoto, T. 1982. Identification of okadaic acid as a toxic component of a marine dinoflagellate Prorocentrum lima. Bull. Jpn. Soc. Sci. Fish. 48:69-72.

Nagahama, Y., Murray, S., Tomaru, A. \& Fukuyo, Y. 2011. Species boundaries in the toxic dinoflagellate Prorocentrum lima (Dinophyceae, Prorocentrales), based on morphological and phylogenetic characters. J. Phycol. 47:178189.

Nakamura, Y., Suzuki, S. -Y. \& Hiromi, J. 1995. Growth and grazing of a naked heterotrophic dinoflagellate, Gyrodinium dominans. Aquat. Microb. Ecol. 9:157-164.

Ok, J. H., Jeong, H. J., Lim, A. S. \& Lee, K. H. 2017. Interactions between the mixotrophic dinoflagellate Takayama helix and common heterotrophic protists. Harmful Algae 68:178-191.

Pearce, I., Handlinger, J. H. \& Hallegraeff, G. M. 2005. Histopathology in Pacific oyster (Crassostrea gigas) spat caused by the dinoflagellate Prorocentrum rhathymum. Harmful Algae 4:61-74.

Psarra, S., Tselepides, A. \& Ignatiades, L. 2000. Primary productivity in the oligotrophic Cretan Sea (NE Mediterranean): seasonal and interannual variability. Prog. Oceanogr. 46:187-204.

Roselli, L., Vadrucci, M. R., Fanelli, F., Ungaro, N. \& Caroppo, C. 2019. First bloom event of the small dinoflagellate Prorocentrum shikokuense in the Mediterranean Sea: cryptogenic or introduced? Mar. Pollut. Bull. 139:197- 
204.

Scheiner, S. M. 1993. MANOVA: multiple response variables and multispecies interactions. In Scheiner, S. M. \& Gurevitch, J. (Eds.) Design and Analysis of Ecological Experiments. Chapman and Hall, New York, pp. 94-112.

Sierra-Beltrán, A. P., Cortés-Altamirano, R. \& Cortés-Lara, M. C. 2005. Occurrences of Prorocentrum minimum (Pavillard) in México. Harmful Algae 4:507-517.

Smayda, T. J. 1997. Harmful algal blooms: their ecophysiology and general relevance to phytoplankton blooms in the sea. Limnol. Oceanogr. 42:1137-1153.

Strathmann, R. R. 1967. Estimating the organic carbon content of phytoplankton from cell volume or plasma volume. Limnol. Oceanogr. 12:411-418.

Strom, S. L. \& Buskey, E. J. 1993. Feeding, growth, and behavior of the thecate heterotrophic dinoflagellate Oblea rotunda. Limnol. Oceanogr. 38:965-977.

Sugahara, K., Kitamura, Y., Murata, M., Satake, M. \& Tachibana, K. 2011. Prorocentrol, a polyoxy linear carbon chain compound isolated from the toxic dinoflagellate Prorocentrum hoffmannianum. J. Org. Chem. 76:3131-3138.

Tango, P. J., Magnien, R., Butler, W., Luckett, C., Luckenbach, M., Lacouture, R. \& Poukish, C. 2005. Impacts and potential effects due to Prorocentrum minimum blooms in Chesapeake Bay. Harmful Algae 4:525-531.

Tillmann, U. \& Hoppenrath, M. 2013. Life cycle of the pseudocolonial dinoflagellate Polykrikos kofoidii (Gymnodiniales, Dinoflagellata). J. Phycol. 49:298-317.

Torigoe, K., Murata, M., Yasumoto, T. \& Iwashita, T. 1988. Prorocentrolide, a toxic nitrogenous macrocycle from a marine dinoflagellate, Prorocentrum lima. J. Am. Chem. Soc. 110:7876-7877.

Verni, F. \& Gualtieri, P. 1997. Feeding behaviour in ciliated protists. Micron 28:487-504.

Vila, M. \& Masó, M. 2005. Phytoplankton functional groups and harmful algae species in anthropogenically impacted waters of the NW Mediterranean Sea. Sci. Mar. 69:3145.

Watts, P. C., Martin, L. E., Kimmance, S. A., Montagnes, D. J. S. \& Lowe, C. D. 2010. The distribution of Oxyrrhis marina: a global disperser or poorly characterized endemic? J. Plankton Res. 33:579-589.

Westfall, J. A., Bradbury, P. C. \& Townsend, J. W. 1983. Ultrastructure of the dinoflagellate Polykrikos. I. Development of the nematocyst-taeniocyst complex and morphology of the site for extrusion. J. Cell Sci. 63:245-261.

Wyatt, T. \& Zingone, A. 2014. Population dynamics of red tide dinoflagellates. Deep Sea Res. Part II: Top. Stud. Oceanogr. 101:231-236.

Yasumoto, T., Seino, N., Murakami, Y. \& Murata, M. 1987. Toxins produced by benthic dinoflagellates. Biol. Bull. 172:128-131.

Yoo, Y. D., Jeong, H. J., Kang, N. S., Kim, J. S., Kim, T. H. \& Yoon, E. Y. 2010. Ecology of Gymnodinium aureolum. II. Predation by common heterotrophic dinoflagellates and a ciliate. Aquat. Microb. Ecol. 59:257-272.

Zingone, A., Siano, R., D’Alelio, D. \& Sarno, D. 2006. Potentially toxic and harmful microalgae from coastal waters of the Campania region (Tyrrhenian Sea, Mediterranean Sea). Harmful Algae 5:321-337. 